DOI 10.31509/2658-607x-2020-3-2-1-34

УДК 574.42

МОНИТОРИНГ СОСТАВА АТМОСФЕРНЫХ И ПОЧВЕННЫХ ВОД В ЛЕСНЫХ ЭКОСИСТЕМАХ: ДОСТИЖЕНИЯ И ПЕРСПЕКТИВЫ

\author{
B.B. Ершов \\ Институт проблем промышленной экологии Севера КНЦ РАН \\ Россия, 184209, г. Апатить, ул. Академгородок $14 a$ \\ E-mail: Slavo91@gmail.com \\ Поступила в редакцию 20.04.2020 \\ Принята в печать 28.05.2020
}

В статье дается обзор российский и зарубежных работ по оценке состава атмосферных выпадений и почвенных вод в лесных экосистемах. Сделано заключение о том, что недостаточно внимание уделяется трансформации химического состава осадков лесными экосистемами с учетом влияния видового состава древостоя и мозаичного строения биогеоценоза (подкроновые, межкроновые пространства, открытые участки). В европейских работах состав атмосферных выпадений и лизиметрических вод обычно изучается в многолетней динамике, что позволяет обнаружить долговременные тренды в изменениях состава атмосферных и почвенных вод и выявить факторы этих изменений. В отечественных работах таких многолетних (более 10 лет) постоянных наблюдений, посвященных влиянию техногенного загрязнения на состав и свойства атмосферных и почвенных вод, не проводилось. Эта задача является весьма актуальной для России и, особенно, для индустриально развитых регионов.

Ключевые слова: лесные биогеоченозы, аэротехногенное загрязнение, атмосферные выпадения, почвенные воды, мониторинг, многолетняя динамика, критические нагрузки

Условия окружающей среды быстро меняются в глобальном масштабе с начала эры индустриализации (Schöpp et. al., 2003; IPCC, 2007). Техническое развитие человечества привело к существенному изменению химического состава атмосферы, гидросферы, педосферы, а также представителей флоры и фауны. Производственная деятельность вызывает трансформацию природных экосистем, степень которой зависит от характера и интенсивности антропогенного воздействия и устойчивости экосистем. Оценка современного состояния экосистем и прогнозирование их развития является важной научной задачей и имеет существенное прикладное значение (Ананьева и др., 2012).

Лесные экосистемы играют важную роль в сохранении экологического равновесия, устойчивого функционирования биосферы, а также в обеспечении материальных и духовных потребностей человека (Смит, 1985). Одним из важных факторов определяющих современное состояние лесных экосистем является аэротехногенное загрязнение. Лесные биогеоценозы аккумулируют загрязняющие вещества, выступая своеобразным трансформатором атмосферных техногенных выпадений, по сути, являясь фильтром биосферного уровня в большом биогенном потоке вещества (Рассеянные элементы, 2004). Поглощая поллютанты антропогенного и естественного происхождения, леса очищают атмосферу, выполняя важную санитарную функцию.

Цель работы - анализ литературных данных о влиянии аэротехногенного загрязнения на лесные биогеоценозы.

Еще в конце прошлого века перед человечеством остро встала проблема охраны окружающей среды от антропогенного воздействия, над лесными экосистемами нависла угроза деградации от загрязнения. Для объективного анализа этой опасности необходимы оценки, 
основанные на количественных измерениях и обобщениях широкого масштаба. Выделяют 3 класса взаимодействий между лесными экосистемами и атмосферными примесями. Взаимодействия 1 класса - характеризуется низким содержанием примесей, влияние их на лесную экосистему, в зависимости от их характера, несет незаметный (безвредный) или стимулирующий эффект. Взаимодействия 2 класса - концентрации примесей несут угнетающий для некоторых компонентов биоты эффект. Взаимодействия 3 класса - высокое содержание примесей, вызывающих нарушения биогеохимических круговоротов и потоков энергии (Смит, 1985).

С конца 19-го века до середины 80-х годов прошлого столетия крупные регионы Европы подверглись негативному воздействию кислотных осадков из-за увеличения антропогенных выбросов поллютантов в атмосферу. Выбросы серы (S) в Европе увеличились в семь раз, а выбросы азота $(\mathrm{N})$ увеличились примерно в пять раз, что коррелировало с аналогичным повышением кислотности осадков (Schöpp et. al., 2003; Engardt et al., 2017). B восьмидесятые годы прошлого века состояние и жизнеспособность лесных экосистем вызвало общественное беспокойство из-за обширного повреждения лесов Центральной Европы, причиной которого являлось загрязнение воздуха, в том числе кислотообразующими соединениями, выпадающими с атмосферными осадками (Schütt et al., 1983; Lammel, 1984). Для глубокого понимания механизмов воздействия атмосферного загрязнения на лесные экосистемы в восьмидесятые и девяностые годы прошлого столетия были предприняты большие исследовательские усилия, которые включали в себя постоянный мониторинг экосистем и моделирование. На основе этих исследований были выявлены следующие последствия воздействия аэротехногенного загрязнения на состояние лесных экосистем (De Vries et al., 2000): повышенные концентрации $\mathrm{SO}_{2}$ в атмосфере вызывают нарушения устьиц и преждевременное старение листьев, нарушение распределения ассимилянтов, приводящее к ослаблению корневой системы, ускоренному выщелачиванию питательных веществ из растений; эвтрофикация из-за выпадений соединений азота $\left(\mathrm{NO}_{3}, \mathrm{NH}_{4}\right)$, вызывает дисбаланс между основными катионами и азотом, что может приводить к усилению стресса от засухи, чувствительности к заморозкам и грибковым болезням, поскольку повышения содержания азота способствует росту надземной биомассы, но скорость роста корней при этом не изменяется; подкисление почвы, то есть снижение $\mathrm{pH}$, приводит к потере основных катионов из почвы, вызывая дефицит питательных веществ (особенно Mg), высвобождение токсичных соединений алюминия, негативно влияющих на рост корней, повышение миграционной активности тяжелых металлов.

Последствия атмосферного промышленного загрязнения вызвали общественную озабоченность и, под эгидой Европейской экономической комиссии Организации Объеденных Наций (UN-ECE) и EC была создана Международная кооперативная программа по оценке и мониторингу воздействия загрязнения воздуха на леса (ICP Forests) в середине 1980-х годов (Lorenz, 1995). Основная цель мониторинга уровня I этой программы (Level I Monitoring Programme) заключалась в получении данных о пространственных и временных изменениях состояния лесных экосистем, а также влиянии факторов стресса, включая атмосферное загрязнение, на эти экосистемы. С течением времени стало ясно, что крупномасштабный мониторинг не в состоянии ответить на вопросы, касающиеся причинноследственных связей, поэтому в 1994 году под эгидой UN-ECE/ICP Forest и EC началась общеевропейская программа интенсивного и непрерывного мониторинга, так называемая программа мониторинга уровня II (Level II Monitoring Programme). В дальнейшем обе эти сети мониторинга стали называться - ICP Forests Level I и Level II (Lorenz and Becher, 2012). В то время как сеть ICP Forests уровня I направлена на получение данных о 
пространственных и временных изменениях, влияющих на состояние леса, сеть уровня II создана для выяснения причинно-следственных связей. В составе показателей, измеряемых при реализации ICP Forests: состояние крон деревьев (степень дефолиации и обесцвечивания), прирост ствола дерева, биоразнообразие напочвенного покрова, химический состав хвои/листьев, почвы, атмосферных выпадений, почвенных вод, метеорологические данные, качество окружающего воздуха, данные о биомассе наземной растительности. Все эти наблюдения проводятся на специально выбранных площадях постоянного наблюдения (Ferretti et. al., 2013).

Созданная в Европе глобальная сеть мониторинга не только помогла оценить степень воздействия аэротехногенного загрязнения на экосистемы, но и позволила принять меры по сокращению подкисляющих и эвтрофицирующих соединений элементов, с помощью ряда протоколов, которые установили допустимые пределы для выбросов некоторых загрязняющих веществ - $\mathrm{NH}_{3}$, $\mathrm{NO}_{\mathbf{x}}$ и $\mathrm{SO}_{2}$ (Maas, Grennfelt, 2016). Европейские ученые отмечают, что для успешной реализации мер по сокращению влияния аэротехногенного загрязнения на экосистемы необходимы многолетние непрерывные наблюдения (Ferm et al., 2019).

Проблема влияния техногенного загрязненияна экосистемы актуальнаи для России, особенно для индустриально развитых регионов Севера, таких как Красноярский край, Свердловская, Челябинская, а также Мурманская области на территории, которых функционируют крупные металлургические комбинаты (Евдокимова и др, 1984; Ярмишко, 1984;Карабань и др, 1985; Ярмишко, Ярмишко, 2002; Derome, Lukina, 2010; Цветков, Цветков 2012; Дерябина, Перетыкин, 2015; Зайцева, 2016; Курпатов и др., 2016; Воробейчик, Кайгородова, 2017; Клюев, Яковенко, 2018; Шепель, 2019 и др.).

Химический состав атмосферных выпадений в виде снега и дождя:

\section{влияние аэротехногенного загрязнения и древостоя}

Атмосферные осадки являются одной из составляющих биогеохимического цикла. Атмосферные выпадения подразделяются на влажные (вещества, достигающие поверхности земли с собственно атмосферными осадками: дождь, снег, иней, туман, роса и т.д.) и сухие (частицы и газы). Количество и качество атмосферных осадков оказывает огромное влияние на состояние лесов. При взаимодействии атмосферных осадков с кронами деревьев происходит как поглощение соединений различных элементов, так и их вымывание из крон. Вымываемые из крон древесных растений вещества могут поглощаться корнями растений, а в период вегетации этот процесс может происходить многократно (Лукина, Никонов, 1996; Кислотные осадки, 1990).

Выпадения в виде снега

Зимние атмосферные выпадения приурочены к периоду биологического покоя. В бореальных лесах продолжительность залегания снегового покрова составляет от 100 до 200 дней в году, что определяет значительную роль осадков в виде снега в биогеохимических циклах (Рассеянные элементы..., 2004). Во время оттепелей происходит выщелачивание веществ из крон деревьев, что существенно влияет на пространственное распределение элементов в снеге (Helmisaari, Malkonen, 1989; Лукина, Никонов, 1996; Pomeroy et al, 1999; Lukina, Nikonov, 2003; Пристова, 2005; Gandois et al., 2010; Мартынюк и др., 2011; De Vries et al, 2014 и др.). Выпавший на земную поверхность снег формирует снежный покров, в нем за время его формирования помимо аэрозольных выпадений, отражающих природный состав атмосферы, накапливаются продукты техногенных эмиссий, которые в составе твердых гидрометеоров (снега, изморози, инея) аккумулируются в снежной толще (Тентюков, 2007). Снежный покров выступает, как один из индикаторов загрязнения не только атмосферных осадков, но и атмосферного воздуха, а 
также последующего загрязнения вод и почв (Воеводова, 1979; Раткин, 2000).

В Швейцарии была проведена многолетняя оценка состава атмосферных выпадений, прошедших сквозь древесный полог и на открытых территориях с 1995 по 2001 гг., которая позволила выявить превышение критических нагрузок азота на экосистемы (Thimonier et. al., 2005; Waldner et. al., 2007). В Западной Европе на 169 участках интенсивного мониторинга были проведены исследования (за период с 1996 по 2001 гг.) по изучению состава атмосферных выпадений и влияния осадков на лесные экосистемы. Это позволило выявить значительное снижение содержания сульфатов в атмосферных выпадениях, как на открытых участках, так и прошедших сквозь лесной полог, тогда как содержание азота снизилось менее значимо (Fisher et. al., 2007). Совместные исследования влияния атмосферных выпадений на растительность на сети мониторинга за период с 1996 по 2000 гг. позволили выявить статистически значимое смещение в сторону нитрофильных видов при высоком содержание азота и к ацидофильным видам при высоком содержании соединений серы в атмосферных осадках (van Dobben, de Vries 2010). Исследования многолетней динамики, с 1995 по 2007 гг., изменений в составе атмосферных выпадений во Франции показали снижение концентраций соединений серы и увеличение показателя $\mathrm{pH}$. По мнению авторов это может быть связанно с сокращением выбросов сернистого газа в Европе, однако, несмотря на снижение выбросов концентрации соединений азота остались неизменными или, наоборот, на некоторых участках увеличились (Pascaud et. al., 2016).

В Польше проводились исследования в хвойных и лиственных лесах с целью оценки трансформации атмосферных осадков, прошедших сквозь древесный полог, а также влияния видового состава древостоев на химический состав атмосферных выпадений. Данные исследования были проведены с января по декабрь 2010 года. Анализ данных проводился по двум периодам зима-весна (с января по май и декабрь) и лето-осень (с июня по ноябрь). Авторами отмечается, что в зимний период обычно происходит повышение уровня загрязнения атмосферы. В период с низкими температурами проводилась оценка влияния загрязняющих веществ, особенно антропогенного происхождения, на состав атмосферных выпадений, прошедших сквозь древесный полог и на открытых участках. Выявлено, что концентрации $\mathrm{Cl}^{-}, \mathrm{SO}_{4}^{2-}, \mathrm{Al}$ и $\mathrm{Zn}$, содержащихся в зимних атмосферных выпадениях, увеличиваются при прохождении осадков сквозь древесный полог хвойных пород. Это объяснялось тем, что стационарная площадь, где проводились исследования, находилась вблизи региона с самой высокой в стране плотностью населения и развитой промышленностью. Концентрации ионов в осадках, прошедших сквозь кроны деревьев обычно выше, чем под кронами лиственных видов деревьев в аналогичной среде обитания из-за более высокой эффективности фильтрации сухих осадков, особенно кислотных ионов. Помимо этого отмечается, что концентрации таких элементов как $\mathrm{Mn}, \mathrm{K}, \mathrm{Mg}, \mathrm{PO}_{4}{ }^{2-}$ в осадках прошедших сквозь кроны хвойных и лиственных лесов, сопоставимы, что указывает на низкую биологическую активность деревьев в зимний период (Kowalska et. al., 2016).

В отечественной литературе существует множество работ по изучению химического состава снежного покрова. Роль снежного покрова в природных процессах стали исследовать еще в прошлом столетии (Воейков, 1949). Анализ данных о его физико-механических свойствах, процесcax его формирования и таяния и т.д. представлен в работах Копанева И.Д. (Копанев, 1982). Трансграничный перенос сульфатов, загрязнение поверхностных вод стали оценивать с конца прошлого века (Глазовский и др., 1983; Василенко и др., 1985; Оболкин, 1991). Значительная часть российских и зарубежных работ проводились на территории Мурманской области, граничащей со скандинавскими странами. 
На Кольском полуострове, в зоне влияния медно-никелевого комбината, были проведены исследования состава атмосферных выпадений в хвойных лесах (Лукина, Никонов, 1996). Авторами отмечается, что зимние атмосферные выпадения характеризуются пониженной минерализацией и концентрацией углерода по сравнению с летними. Это объясняется незначительной активностью организмов в зимнее время. Различия в составе снеговых вод в подкроновых и межкроновых пространствах выражены менее четко, чем в период вегетации. При приближении к источнику загрязнения наблюдается достоверное увеличение концентраций никеля, меди, железа, хлора, нитратов, сульфатов, аммония и кальция в составе снеговых вод, также как и увеличение, их кислотности.

Изучение состава снеговых выпадений, как индикатора аэротехногенного загрязнения окружающей среды, в зоне влияния комбината «Печенганикель», позволило рассчитать границы локального высокого уровня загрязнения снежного покрова. Разработан метод расчета ретроспективных и перспективных суммарных («сухое» и «мокрое» выпадение) аэротехногенных нагрузок (на период максимального снегонакопления) на любые выделенные природнотерриториальные комплексы (Раткин и др., 1998). Данный метод позволил определить границы локального высокого уровня загрязнения для сульфатов - 58-60 км, для никеля и меди - 28-30 км. Установлено, что вымываемость из атмосферы никеля со снегом на $10 \%$ больше, чем с дождем, а меди на 30\% выше, чем никеля. Рельеф местности, климатические условия, особенности примеси и источника определяют неодинаковую аэротехногенную нагрузку на экосистемы в зоне локального загрязнения (Раткин, 2000).

Проводилась оценка состава и свойств снеговых выпадений на разных стадиях дигрессии сосновых и еловых лесов на Кольском полуострове за период с 1991 по 1997 гг. В фоновых еловых лесах отмечается обогащение подкроновых осадков в зимнее время, в тоже время общее количество веществ, поступающих в межкроновые пространства выше, чем под кронами, что обусловлено меньшим количеством осадков, поступающим в древесные парцеллы. В сосновых лесах концентрация загрязняющих веществ менее значительна, а пространственные различия выражены менее заметно, чем в еловых лесах. В дефолиирующих лесах концентрации поллютантов значительно возрастают по сравнению с фоном, отмечается увеличение поступления элементов питания $\left(\mathrm{K}, \mathrm{P}, \mathrm{NH}_{4}, \mathrm{Mn}, \mathrm{Zn}\right)$ под древесным пологом, что связано с увеличением количества снеговых осадков, проникающих сквозь кроны, вследствие их изреженности, как в еловых, так и в сосновых лесах. В техногенных редколесьях, также как и в дефолиирующих лесах, по сравнению с фоном отмечается существенное возрастание концентраций основных поллютантов (меди, никеля и серы), распределение выпадений по площади довольно равномерное, что также обусловлено сильной изреженностью крон и гибелью большинства деревьев, в сосновых и еловых лесах (Рассеянные элементы..., 2004).

На Кольском полуострове была проведена оценка химического состава атмосферных выпадений в 11 км от комбината «Североникель» за период с 2005 по 2011 гг. (Kashulina et al., 2014). В ходе данного исследования было выявлено, что за изучаемый период в снеговых водах концентрации $\mathrm{SO}_{4}{ }^{2-}$ в 4 раза превышали фоновые значения, концентрации $\mathrm{Ca}$ и $\mathrm{Mg}$ были выше в 5-6 раз по сравнению с фоном. Содержание тяжелых металлов в снеге вблизи комбината превышали фоновые значения для $\mathrm{Ni}$ в $2500, \mathrm{Cu}-1500$ и для $\mathrm{Co}$ в 400 раз по сравнению с фоном. Отмечается, что основным источником загрязнения снежного покрова являются высококонцентрированная техногенная пыль из низколежащих источников (окна, двери, вентиляционные выхлопы, транспортировка руды и концентрата). Помимо этого, было выявлено, что концентрации меди и никеля в снеговых водах практически не менялись с 1994 года, что связанно со значительным количеством 
техногенной пыли, несмотря на постепенное сокращение выбросов комбинатом (Kashulina et al., 2014).

В Республике Коми в 1996-1998 гг. и 2005-2007 гг., проводились исследования, химического состава снежного покрова в лесных экосистемах в зоне влияния ЦБП (целлюлозно-бумажного производства). В результате исследований было выявлено, что снеговые выпадения исследуемых таежных ландшафтов отличаются кислой и слабокислой реакцией. Древостои, как правило, вызывают подкисляющий эффект. Наблюдается увеличение концентраций калия, натрия, марганца и сульфатов, а также снижение содержания кадмия, никеля и нитратов в снежном покрове в подкроновых пространствах, по сравнению с межкроновыми. Выбросы ЦБП оказывают значительное влияние на содержание $\mathrm{C}_{\text {орг }}, \mathrm{HCO}_{3}{ }^{-}, \mathrm{SO}_{4}{ }^{2-}, \mathrm{Na}^{+}, \mathrm{Ca}^{2+}$, $\mathrm{Mn}, \mathrm{Ni}$ и $\mathrm{Fe}$ в снеговых выпадениях. Большинство определяемых компонентов снежного покрова лесных насаждений выше, чем в фоновом районе (Пристова, Василевич, 2010).

В лесных экосистемах Московской, Вологодской и Костромской областей были проведены исследования (2013-2014 гг.) состава и пространственного распределения атмосферных выпадений минерального азота. Авторы заключают, что на концентрацию в атмосферных выпадениях минерального азота влияют, в основном, характер выбросов и специализация промышленных предприятий, а повышение эмиссий нитратов также связанно с выбросами автотранспорта. Установлено, что концентрация минерального азота в снежном покрове лесов определяется, в первую очередь, интенсивностью антропогенной эмиссии, а не типом древостоев, а также, что древостои существенно увеличивают концентрацию минерального азота (аммоний и нитрат) в снеговых водах (Кудреватых, 2017).

Таким образом, изучение химического состава снега и его влияния на лесные экосистемы посвящено множество работ зарубежных авторов и ряд российских работ. Многие зарубежные авторы исследуют снеговые выпадения не отдельно, а в комплексе с дождевыми, анализируют всю сумму осадков за год или по сезонам: декабрь-февраль (зима), мартмай (весна), июнь-август (лето) и сентябрьноябрь (осень). Однако в зарубежных исследованиях редко уделяется внимание влиянию микромозаичной структуры биогеоценоза (подкроновые и межкроновые пространства) на состав атмосферных выпадений. В этих исследованиях выделяют осадки под пологом леса и на безлесных территориях. При этом в зарубежных работах состав снеговых вод, как правило, изучается в многолетней динамике, тогда как в отечественных работах такие многолетние (более 10 лет) постоянные наблюдения довольно редки (Ershov et al., 2016). На примере лесов Мурманской области дан анализ вариабельности состава снеговых вод в сосновых и еловых лесах на разных стадиях техногенной дигрессии с учетом многолетней (около 20 лет) динамики и микромозаичного строения лесного покрова. Показано, что подкроновые снеговые воды еловых и сосновых лесов богаче соединениями элементов, чем межкроновые, что обусловлено их вымыванием и выщелачиванием из крон древесных растений. Снеговые воды еловых лесов отличаются высокими концентрациями соединений элементов по сравнению с сосновыми лесами, что обусловлено сорбирующей способностью крон ели. Многолетняя динамика состава снега демонстрирует снижение содержания основных поллютантов в фоновых условиях и дефолиирующих лесах, как в подкроновых, так и в межкроновых пространствах, что связанно со снижением выбросов. Показано, что основными факторами динамики состава снеговых вод в лесах Кольского полуострова являются древесные растения-средообразователи и воздушное промышленное загрязнение.

Выпадения в виде дождя

Выпадения в виде дождя также играют важную роль в биогеохимических циклах в лесных экосистемах. Бесснежный период (дожди) разделяется на две принципиально различные части: вегетационный сезон и периоды относительного биологического 
покоя (весна и осень). Атмосферные выпадения в виде дождя характеризуются наиболее ярко выраженным взаимодействием их с древесным пологом, особенно в период вегетации растений. В бесснежный период концентрация веществ в атмосферных осадках заметно увеличивается, по сравнению с зимним периодом, что связанно с активным функционированием лесного биогеоценоза (Рассеянные элементы..., 2004). В межкроновых пространствах атмосферные выпадения имеют, в основном, атмогенный характер - состав выпадений определяют атмосферные осадки, в древесных парцеллах они приобретают аутогенный (биогенный) характер (Никонов, Лукина 2000; Лукина и др., 2008). При взаимодействии дождевых вод с пологом леса происходят физико-химические реакции, которые способны изменить кислотность и концентрацию большинства элементов, содержащихся в них (Карпачевский, 1981; Медведев и др., 1986; Matzer, Meiwes, 1994; Шильцова, 2006). В работе А. Тимонир (Thimonier, 1998) отмечается, что изучение состава и свойств атмосферных выпадений в виде дождя, как на открытых участках, так и прошедших через древесный полог, дает ценную информацию о содержании в атмосферных осадках химических веществ, вызывающих подкисление или эвтрофикацию.

На северо-западе Германии проводились исследования химического состава дождевой воды, прошедшей сквозь древесный полог, и на открытых участках в дубовых, березовых и сосновых типах леса. Показано, что на концентрацию химических соединений в дождевых выпадениях, прошедших сквозь древесный полог, существенное влияние оказывает, как видовой составы древостоя, так и расстояние от источника загрязнения. Помимо этого, выявлены различия в скорости осаждения аммония, азота, калия и железа, которые объясняются различной проекцией кроны деревьев, а скорость осаждения кальция, магния, марганца и цинка зависит, главным образом, от вида деревьев, так как выщелачивание этих катионов выше у лиственных пород деревьев по сравнению с хвойными. Выщелачивание элементов из крон лиственных пород деревьев и обогащение ими атмосферных осадков особенно сильно проявляется у таких видов деревьев, как Betula pubescens и Betula pendula. Уровень выщелачивания катионов сильнее всего проявляется в течение вегетационного периода, что приводит к более высоким концентрациям элементов в осадках, прошедших сквозь древесный полог весной, летом и ранней осенью (Herrmann et. al., 2006).

Исследования сухих и влажных атмосферных выпадений в Италии показали, что лесной покров сорбирует $\mathrm{SO}_{4}{ }^{2-}, \mathrm{NO}_{3}^{-}$и $\mathrm{Na}^{+}$эффективнее, чем это происходит на безлесных территориях. Объем дождевых выпадений в подкроновых пространствах был ниже, чем на открытых территориях. Дополнительно отмечается, что перехват дождевых выпадений лесным пологом зависти от типа растительности. Разница между осадками, прошедшими сквозь древесный ярус и выпадающих на открытых пространствах для лиственных деревьев, составляет от 10 до $15 \%$, а в хвойных лесах разница увеличивается до 23-24\% (Balestrini et. al., 2007).

Исследования трансформации атмосферных осадков лиственными и хвойными древостоями в Польше показали, что интенсивные процессы ионного обмена между кроной и дождем в вегетационный период приводят к увеличению выпадений катионов $(\mathrm{K}, \mathrm{Ca}$ и $\mathrm{Mg})$, как в лиственных, так и в хвойных лесах. Видовой состав древостоя значительно влияет на осаждение, состав осадков и зависит от региона страны. Хвойные виды (сосна и ель) вызывают подкисление осадков, тогда как лиственные породы (дуб и бук) повышают значение $\mathrm{pH}$. Более высокие выпадения ионов $\mathrm{K}, \mathrm{Mg}$ и $\mathrm{Mn}$ наблюдаются в осадках прошедших сквозь кроны сосновых и дубовых насаждений, по сравнению с буковыми и еловыми (Kowalska et. al., 2016).

В средиземноморских лесных экосистемах восточного побережья Адриатического моря с апреля 2017 года по 
декабрь 2018 года проводились оценки состава атмосферных осадков и показателей жизнеспособности деревьев. Результаты показали, что выпадения азота с атмосферными осадками, прошедшими сквозь полог сосновых лесов (Pinus halepensis $u$ Pinus nigra), выше по сравнению с открытыми участками, в дубовых лесах (Quercus pubescens, Quercus ilex) данная тенденция отсутствует. Самые низкие концентрации азота отмечаются в сосновых лесах, а самые высокие в дубовых лесах (Jakovljevic et. al., 2019).

Исследования трансформации состава и свойств атмосферных выпадений в виде дождя древесным пологом изучались и отечественными учеными (Пьявченко, Сиберева, 1959; Поздняков, 1956; Морозова, Куликова, 1974; Учватов, Глазовский, 1984; Елпатьевский, 1993; Хрусталева, 2002 и др.). Проходящие сквозь полог атмосферные осадки не только смывают с листьев осевшую пыль, но и насыщаются продуктами метаболизма растений и других организмов, а также выщелачивают часть элементов из живых клеток, активно воздействуя на биологический круговорот веществ. Многие исследователи отмечали подкисление дождевых вод органическими и минеральными кислотами, при контакте с древесным пологом, что способствует переводу химических соединений в доступную для корней растений форму, а также увеличению концентраций в выпадениях многих химических элементов. Наибольшее содержание таких элементов и соединений элементов как азот, гидрокарбонат, сера, сульфаты, калий, натрий, цинк и медь наблюдается именно в подкроновых осадках (Медведев и др., 1986; Никонов, Лукина, 2000, Марунич и др., 2006; Арчегова, Кузнецова, 2011; Робакидзе и др., 2013 и др.).

На Кольском полуострове проводились исследования состава атмосферных выпадений в хвойных лесах при учете влияния аэротехногенного загрязнения (Лукина, Никонов, 1996). Авторами отмечается, что основное количество тяжелых металлов и кислотообразующих веществ выпадает именно в период вегетации. Состав атмосферных выпадений в лесных биогеоценозах определяется степенью дефолиации и густотой древостоя, а их кислотность интенсивностью выщелачивания элементов из крон деревьев. При приближении к комбинату отмечается существенное возрастание содержания элементов, которые входят в состав выбросов. Более кислые, чем в фоновых условиях, атмосферные осадки в дефолиирующих лесах, способствуют выщелачиванию основных катионов, чем и объясняется их более высокие концентрации в дождевых подкроновых водах. В техногенных редколесьях отмечается возрастание кислотности дождевых атмосферных выпадений, а также снижение концентраций $\mathrm{Ca}, \mathrm{Mg}, \mathrm{K}$, $\mathrm{Mn} \mathrm{и} \mathrm{NH}_{4}^{+}$из-за отсутствия древесного полога.

На Кольском полуострове характер трансформации атмосферных выпадений двумя доминирующими в бореальных лесах древесными породами елью и сосной - сходен, осадки, прошедшие через древесный полог, становятся кислыми и обогащаются химическими элементами. Тем не менее, степень преобразования различна, ель осуществляет более глубокую трансформацию, чем сосна, что особенно ярко выражено в выпадениях в виде дождя. Более глубокая трансформация обусловлена наличием плотной и протяженной кроной ели по сравнению с сосной (Кислотные осадки, 1999).

Оценка состава и свойств выпадений в виде дождя на разных стадиях дигрессии сосновых и еловых биогеоценозов на Кольском полуострове за период с 1991 по 1997 гг. показала, что на фоновой территории в бесснежный период концентрации веществ в атмосферных выпадениях заметно увеличиваются, по сравнению с периодом биологического покоя. В составе дождевых выпадений доминировал углерод, из катионов кальций и аммоний из анионов - сульфаты. В дефолиирующих сосновых и еловых лесах отмечается резкое возрастание концентраций сульфатов, никеля и меди в дожде, что обусловлено влиянием 
аэротехногенного загрязнения на древесный полог, также отмечается повышение концентраций кальция, марганца и магния, что объясняется выщелачиванием этих элементов из крон кислыми осадками. В еловых и сосновых техногенных редколесьях выявленные в дефолиирующих лесах изменения в составе дождевых выпадений сохраняются и усугубляются. В еловых лесах наблюдается отсутствие парцеллярных различий в поступлении элементов в связи с сильным разрушением древесного яруса, в сосновых лесах парцеллярные различия сохраняются, количество элементов, поступающих в подкроновые пространства выше, чем между крон (Рассеянные элементы..., 2004).

В зоне влияния медно-никелевого комбината «Североникель» проводились другие, двухлетние (2001-2002 гг.) исследования влияния выбросов горнометаллургической промышленности на химический состав атмосферных выпадений в виде дождя. Для отбора дождевых выпадений были выбраны 6 площадок, находящихся на различном удалении от комбината от 1 до 17 км, с учетом распределения розы ветров. Авторами отмечается, что в наибольших количествах в атмосферный воздух Мурманской области с выбросами горнометаллургического производства поступают сульфаты, а также медь и никель, в результате влияния этих поллютантов в окрестностях комбината «Североникель» образовались обширные зоны деградации почвенно-растительного покрова. Для химического состава дождевых выпадений Мончегорского полигона характерна крайняя изменчивость в пространстве и времени, значения $\mathrm{pH}$ находятся в широком диапазоне от 4 до 7. Практически все химические элементы, входящие в состав атмосферных выбросов комбината, не имеют максимальных значений вблизи него, максимумы концентраций наблюдаются на расстоянии 5-10 км. Средние концентрации $\mathrm{Ni}, \mathrm{Cu}, \mathrm{Zn}, \mathrm{Mo}, \mathrm{V}$, $\mathrm{Ag}$ в атмосферных выпадениях превышают значения ПДК рбхз (Даувальтер и др., 2009).
На Кольском полуострове Г.М. Кашулиной (Kashulina et al., 2014) проводились исследования состава атмосферных выпадений вблизи комбината «Североникель» с 2005 по 2011 гг. В дождевых водах у плавильного завода концентрации $\mathrm{SO}_{4}{ }^{2-}$ в 4 раза, а концентрации основных катионов (Са и $\mathrm{Mg)}$ в 5-6 раз превышали фоновые значения. Содержание тяжелых металлов в дожде были выше на порядок и более, чем на фоновой территории: для $\mathrm{Ni}$ в $146, \mathrm{Cu}$ в 80 и Со в 50 раз, чем на фоновой территории. Отмечается, что доминирующим источником загрязнения дождевых вод являются отфильтрованные газопылевые выбросы и дымовые трубы, сокращение выбросов самим комбинатом значительно уменьшило количество загрязняющих веществ, поступающих из труб в дождевые воды.

Оценка влияния древесных растений на химический состав атмосферных осадков в виде дождя в процессе восстановления среднетаежных лесов в 17 км от города Сыктывкар, с 2006 по 2008 гг. показала, что трансформацию дождевых выпадений определяет древесное растениеэдификатор. Увеличение концентраций элементов биогенов наблюдается от весны к лету и осени. Состав осадков, прошедших сквозь древесный полог лиственных и хвойных древесных растений, различается, особенно, по содержанию органического углерода, калия и кальция. В межкроновых пространствах по сравнению с подкроновыми концентрации элементов биогенного происхождения меньше, отмечаются более резкие их колебания в течение вегетационного периода. Дождевая вода, собранная под травянистой растительностью, отличается меньшей концентрацией калия, кальция и магния, чем под древесными растениями (Арчегова, Кузнецова, 2011).

В исследованиях, проводившихся в 2011 году в зоне влияния Марийского завода силикатного кирпича и в 2012-2014 гг. в заповеднике «Большая Кокшага» рассматривается влияние аэрального поступления веществ на их круговорот в лесных экосистемах. Для оценки 
аэрального поступления химических элементов и трансформации их при взаимодействии с кронами деревьев был разработан метод тканевых повязок, который дополняет существующие методы, позволяя оценивать экзометаболиты растений по вовлечению их в круговорот. Количество и состав атмосферных выпадений, как дождевых, так и снеговых значительно варьирует в пространстве и времени, при взаимодействии с древесным пологом, существенно изменяется их состав, а степень трансформации осадков зависит от вида древесных растений, условий произрастания и фазы сезонного развития. Отмечается, что вымывание кальция и стронция из полога березняков и сосняков, произрастающих на бедных песчаных почвах, где отмечается острый дефицит элементов минерального питания, проявляется гораздо сильнее, чем в пойменном древостое, где дефицита не наблюдается. На основании этого сделан вывод о том, что деревья способны регулировать процесс своего минерального питания и биологический круговорот в лесных экосистемах, выделяя через крону и ствол необходимые экзометаболиты, состав и концентрация которых зависит от видового состава древостоя и условий среды (Демаков, Исаев, 2015).

Таким образом, изучению химического состава дождевых вод и его влияния на лесные экосистемы посвящено множество российских и зарубежных работ. Особое внимание уделяется трансформации химического состава осадков лесными экосистемами с учетом влияния видового состава древостоя. В зарубежных исследованиях редко уделяется внимание влиянию микромозаичной структуры биогеоценозана состав выпадений в виде дождя. В европейских работах состав дождевых вод, как правило, изучается в многолетней динамике как в ходе реализации программы ICP Forests с 1995 года до настоящего времени, так и в других исследованиях, например в Швеции изучение выпадений сульфатов, нитратов, аммония и др. соединений с 1955 по 2017 гг. (Ferm et al., 2019).
Таким образом, многолетние исследования позволяют обнаружить долговременные тренды в изменениях состава дождя и выявлять факторы этих изменений. Однако, в зарубежных работах не уделяется внимания влиянию микромозаичной структуры лесов на состав дождевых выпадений, а в отечественных работах многолетние (более 10 лет) постоянные наблюдения, посвященные влиянию техногенного загрязнения на состав и свойства дождевых вод, носят единичный характер (Ершов и др., 2020). На примере лесов Мурманской области показано, что химический состав дождевых вод характеризуется значительным внутрии межбиогеоценотическим варьированием. На основе многолетних (18 лет) данных подтверждается, что содержание элементов в дожде в подкроновых пространствах выше, чем в межкроновых, при этом в ельниках по сравнению с сосняками концентрации и выпадения элементов значимо выше, что объясняется разной сорбирующей способностью крон деревьев. Многолетняя динамика концентраций элементов в дождевых водах хвойных лесов отличается высокой вариабельностью. В фоновых условиях выявлено повышение концентраций никеля в период 2013-2017 гг., что объясняется возрастанием содержания поллютантов в аэрозолях, распространяющихся на значительные расстояния. древостоя И аэротехногенного загрязнения на состав почвенных вод

Почва - важнейший компонент лесной экосистемы, она служит аккумулятором для большинства элементов, вовлекаемых в биогеохимические циклы. Почва является пористым телом, поэтому в ней разделяют три главные составные части - жидкую, твердую и газообразную. Важнейшим источником влаги в почве являются атмосферные осадки. Вода, поступающая из атмосферы, содержит растворенные в ней газы и другие вещества, поэтому на поверхность почвы поступает не чистая вода, а некий раствор различных газов, солей и других веществ. Из этого следует, что почвенная влага это некоторый раствор, 
который принято называть почвенным раствором или почвенной водой (Роде, 1955). Рассматривая почвенную влагу как одну из самых важных категорий природных вод в биосфере, В.И. Вернадский считал ее «основным субстратом жизни» и «основным элементом механизма биосферы» (Вернадский, 1960). Она отвечает за подвижность элементов в почвенном профиле, определяя перераспределение веществ по генетическому профилю почвы и вынос их в сопредельные среды (Раудина, 2015). Почвенный раствор является наиболее активной фазой почвы. Именно в нем происходит большинство всех химических реакций, протекающих в почве. Вода является своеобразным связующим звеном в системе: организмы почвы-порода-атмосфера. Обмен веществ осуществляется в основном через жидкую фазу - почвенный раствор, грунтовые и поверхностные воды (Ковда, 1985). Состав почвенной воды это результат комплекса различных процессов, таких как: выветривание, реакция нейтрализации и буферирования в почвах, выпадение осадков из атмосферы, поглощения растениями, латеральные и вертикальные потоки воды и выщелачивание (Мотузова и др., 2009). Химический состав почвенных вод позволяет получить информацию, как о доступности элементов питания, так и о негативном воздействии поллютантов на лесные экосистемы.

Многие зарубежные авторы широко используют химический состав почвенных вод в качестве диагностического инструмента для мониторинга биогеохимических циклов в лесных экосистемах. В целях лучшего понимания механизмов влияния загрязнения воздуха и других факторов стресса на состояние лесных экосистем, был установлен второй, интенсивный уровень мониторинга по программе ICP Forests. Результаты этой интенсивной общеевропейской программы показали, что концентрации $\mathrm{NO}_{3}$ в почвенном растворе превышали критерий качества воды в ЕС на 9\% рассматриваемых участков, а отношение концентраций основных катионов и алюминия превышали критическое значение на 30$39 \%$ участков в зависимости от рассматриваемого слоя в 1997 году. Полученные данные также позволили сделать вывод о том, что высвобождение ионов алюминия является доминирующим процессом буферирования кислых почв, а в менее кислых почвах буферирование происходит за счет основных катионов. Изменение концентраций основных ионов в почвенных водах может быть объяснено различиями в атмосферных выпадениях и метеорологических условий (de Vries et al., 2003).

Исследование состава почвенных вод в европейских широколиственных и хвойных лесах (данные за период с 1995 по 1998 год) показало, что концентрации нитратов в почвенном растворе характеризуются выраженной сезонной динамикой, летние концентрации на 25\% выше, чем зимние. Помимо этого, было выявлено, что хвойные и широколиственные леса по-разному реагируют на выпадения соединений $\mathrm{N}$, поэтому их необходимо анализировать отдельно. Концентрации нитратов в почвенном растворе реагируют на изменение содержания азота в атмосферных выпадениях, и это более заметно в широколиственных лесах, чем в хвойных, главным образом, потому что широколиственные леса функционируют на более плодородных почвах, чем хвойные леса (Kristensen et al., 2004).

B Великобритании на участках интенсивного мониторинга был проведен многолетний (12 лет) анализ состава атмосферных выпадений и почвенных вод. Оценка многолетней динамики состава атмосферных осадков подтвердила успешное осуществление политики сокращения выбросов в Великобритании. Многолетние тенденции динамики химического состава почвенного раствора показали постепенное снижение содержания сульфатов и алюминия, а также увеличение показателя $\mathrm{pH}$. Концентрации растворенного органического азота увеличивалась в атмосферных осадках на открытых территориях и при контакте с пологом леса, а также в почвенных водах на большинстве исследуемых участков. 
Наблюдалось снижение нитратов в почвенных водах на участках с высоким выпадением азота из атмосферы. Установлено, что увеличение содержания в почве растворенного органического углерода может быть объяснено заметным снижением загрязнения, либо изменением в температуре почвы, либо увеличением микробиологической активности (Vanguelova et al., 2010).

В северной части Бельгии были проведены исследования химического состава в атмосферных выпадениях и почвенном растворе за семнадцатилетний

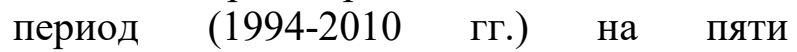
мониторинговых станциях с хвойными и лиственными биогеоценозами. В ходе исследования было выявлено снижение выпадений сульфатов и аммония на всех исследуемых участках, а также нитратов, но только в лиственных лесах. Уменьшение выпадений азота и серы сопровождалось снижением выпадений основных катионов $\left(\mathrm{BC}=\mathrm{Ca}^{2+}+\mathrm{K}^{+}+\mathrm{Mg}^{2+}\right)$, а в целом происходило снижение потока подкисляющих веществ с выпадениями. Содержание аммония, нитратов, сульфатов и основных катионов в почвенном растворе снижалось с уменьшением атмосферных выпадений этих элементов. Выпадения кислотообразующих соединений $\mathrm{N}$ и $\mathrm{S}$ в хвойных и лиственных лесах Бельгии значительно сократились в период с 1994 по 2010 год, но лесные почвы все еще находятся в неблагоприятном состоянии. Критические нагрузки были превышены, а подкисление почвы вследствие антропогенного воздействия продолжалось, что можно объяснить одновременным уменьшением содержания основных катионов, что оказывало влияние на процессы катионообмена (Verstraeten et al., 2012).

В Великобритании был проведен многолетний (с 1993 по 2011 года) анализ состава почвенных вод на лесных и безлесных участках, для выявления влияния снижения атмосферного загрязнения, а также климатических изменений на динамику концентраций растворенного органического углерода (DOC). Данное исследование показало, что наблюдаемые лугово-пастбищные и лесные почвы существенно восстановились после антропогенного подкисления, однако, маловероятно, что эти изменения могут быть связаны с климатическими изменениями. Временные модели многолетних тенденций концентрации DOC варьирует между участками по причинам, которые могут быть связаны со свойствами почвы, растительным покровом, величиной и источником выбросов кислотообразующих веществ (антропогенным или природным). Тенденции DOC были в основном связаны с временными изменениями кислотосодержащих выпадений. Изменения в составе DOC поверхностных вод в значительной степени соответствуют изменениям DOC верхнего слоя почвы. Если выпадения кислотообразующих веществ продолжает снижаться, можно наблюдать увеличение концентраций DOC в поверхностных горизонтах и прилегающих поверхностных водах (Sawicka et al., 2016).

За период с 1995 по 2012 гг. были проведены исследования изменения состава почвенных вод из минеральных горизонтов в европейских лесах в связи с уменьшением выпадений кислотообразующих веществ. Полученные данные позволили выявить значительное снижение концентраций сульфатов в почвенном растворе на 52\% на глубине 10-20 см и 40\% на глубине 40-80 см, концентрации нитратов снижались только на глубине 4080 см. Снижение концентраций кислотных анионов сопровождалось значительным снижением концентраций основных катионов (кальция, магния и калия) и $\mathrm{Al}_{\mathrm{tot}}$, изменения кислотности почвенного раствора были не однонаправленными. Полученные результаты свидетельствовали о нелинейной реакции между снижением выбросов и изменениями в кислотности почвенного раствора и подчеркивали важность долгосрочного мониторинга при оценке реакции экосистем на снижение атмосферного загрязнения (Johnson et al., 2018).

Исследования состава почвенных вод, который может быть использован для 
ранней диагностики процессов деградации почв под воздействием техногенного загрязнения, почвенного мониторинга и оценки критических нагрузок проводились и отечественными учеными (Тяжелые металлы ..., 1980; Карпухин и др., 1993; Лукина, Никонов, 1996; 1998; Мотузова, 2001; Копцик, 2004; Мотузова и др., 2009; Lukina et al., 2018; и др.).

На Кольском полуострове проводятся исследования состава и свойств почвенных вод в лесах на северном пределе распространения, как в естественных условиях, так и в условиях загрязнения эмиссиями самых мощных в Северной Европе источников выбросов в атмосферу диоксида серы и тяжелых металлов - горнометаллургических комбинатов «Печенганикель» и «Североникель». Согласно полученным результатам в почвенных водах бореальных лесов можно наблюдать значительную внутрипрофильную изменчивость, которая выражается в снижении концентраций всех элементов с глубиной и объясняется наличием биогеохимических барьеров. Также можно наблюдать выраженную внутрибиогеоценточескую изменчивость, почвенные воды в подкроновых пространствах более концентрированные и кислые, чем в межкроновых, что обусловлено формированием интенсивных потоков кислотообразующих веществ с кроновыми и стволовыми водами. Отмечают вариабельность состава почвенных вод в зависимости от типа биогеоценоза: показано, что в почвенных водах еловых лесов концентрации элементов, как правило, выше, чем в сосновых лесах. Почвенным водам бореальных лесов свойственна ярко выраженная сезонная вариабельность: как правило, концентрация углерода и положительно зависящий от нее показатель кислотонейтрализующей способности ANC увеличивается от весны к осени. При приближении к источнику загрязнения отмечается нарушение функционирования всех компонентов биогеоценоза, в связи с этим происходит снижение концентраций элементов питания в почвенных водах и показателя ANC, наблюдается возрастание концентраций соединений элементов входящих в состав выбросов. Данные изменения наиболее заметны в древесных, особенно в еловых, парцеллах из-за высокой сорбирующей способности крон хвойных деревьев (Лукина, Никонов, 1996, 1998; Кислотные осадки ..., 1999, Лукина и др., 2008).

Почвенные воды подзолов в зонах влияния, функционирующих на Кольском полуострове, обладают кислой реакцией, высоким содержанием органического вещества, среди катионов доминируют - Са и K, среди анионов - анионы органических кислот и сульфаты. Почвенные растворы в ельниках более кислые концентрированные по сравнению с сосняками. При приближении к источнику загрязнения резко возрастают концентрации тяжелых металлов $(\mathrm{Ni}, \mathrm{Cu}, \mathrm{Cd})$, при этом медь более прочно фиксируется органическим веществом, а никель вымывается в нижележащие почвенные слои. Концентрации органического вещества, калия, натрия, а под ельниками еще и кальция, марганца и цинка при техногенной трансформации уменьшается. При увеличении атмосферного загрязнения концентрации растворимых органических кислот в водах подстилки снижается, а сульфатов - возрастает. При сравнении почвенных вод органогенных и минеральных горизонтов с увеличением загрязнения наблюдается нивелирование различий, что свидетельствует о частичной потере подстилкой функции биогеохимического барьера (Копцик и др., 2007).

В почвенных водах сосновых и еловых лесов Кольского полуострова проводились исследования качественного и количественного состава низкомолекулярных органических кислот (НАК) на разных стадиях техногенной дигрессии. Исследования состава вод фоновых территорий выявили, что среди НАК доминирует лимонная кислота. Важным источником поступления НАК в почвенные воды является выщелачивание из крон деревьев, однако, в середине вегетационного периода крона может выполнять барьерные функции. С миграцией вод по органогенному горизонту 
почв происходит их обогащение органическими кислотами. Содержания НАК в почвенных водах фоновых территорий зависит от типа биогеоценоза, его парцеллярной структуры и сезона года (Артемкина и др., 2008). При приближении к источнику загрязнения наблюдается уменьшение концентраций лимонной кислоты в почвенных водах еловых лесов в подкроновых и межкроновых пространствах. С увеличение техногенной нагрузки отмечается отсутствие различий концентраций лимонной кислоты на внутрибиогеоценотическом уровне. Атмосферное загрязнения оказывает влияние на концентрации НАК, через изменение состава растительности и опада (Артемкина и др., 2011).

В Московской области проводился четырехлетний мониторинг природных вод в широколиственно-хвойных лесах с целью изучения концентраций и потоков растворимого органического углерода (РОУ) в системе атмосферные осадки подкроновые воды - почвенные воды. В результате исследования было установлено, что атмосферные осадки имеют низкие и сравнительно постоянные концентрации органического углерода, при контакте с древесным пологом они обогащаются углеродом, в наибольшей степени в сосново-еловом лесу. Почвенные воды имеют высокую концентрацию РОУ, изменяющейся в широких пределах в зависимости от типа биогеоценоза, свойств и глубины почвы. Наблюдалась значительная вариабельность концентраций углерода в подкроновых и почвенных водах, как по сезонам, так и по годам. Выявлено, что растворимые органические соединения атмосферного и кронового происхождения незначительно влияют на углерод почвенных вод. В условиях промывного водного режима в подзолистых почвах, в подкроновых пространствах хвойных и смешанных лесов, вынос органического углерода с почвенными водами в вегетационный период преобладает над поступлением с осадками (Султанбаева и др., 2015).

В заповеднике «Кивач» Кондопожского района республики Карелия проводились исследования (с 2009 по 2011 гг.) химического состава почвенных вод в хвойных лесах средней тайги. Отмечается, что в ионном составе почвенных вод преобладали калий, кальций, сульфаты и гидрокарбонаты, величина $\mathrm{pH}$ соответствовала слабокислым водам. Среди соединений азота доминировал органический азот, отмечалось высокое содержание органических веществ и литофильных элементов, среди тяжелых металлов наибольшим содержанием отличались цинк и медь. С глубиной почвенного профиля ельника и сосняка наблюдалось уменьшение концентраций калия и кальция и увеличение концентраций сульфатов, натрия, гидрокарбонатов и величины $\mathrm{pH}$, а также уменьшение содержания общего азота, а в сосняке и фосфора, и органических веществ в почвенных водах. В обоих почвенных профилях установлено уменьшение содержания алюминия и кремния с глубиной. В профиле сосняка отмечалось увеличение содержания кадмия и меди и уменьшение цинка, а в ельнике увеличение кадмия, свинца и цинка и уменьшение кобальта, никеля и меди (Бахмет и др., 2011; Кравченко, 2016).

Таким образом, изучение состава почвенных вод остается актуальной проблемой. Как и в случае изучения атмосферных выпадений, в зарубежных работах, посвященных изучению состава почвенных вод, влиянию микромозаичной структуры биогеоценоза на состав почвенных вод не уделяется внимания, а в российских работах редко встречается многолетние исследования (Ершов и др., 2019). На примере лесов Мурманской области установлена значительная внутрии межбиогеоценотическая вариабельность состава почвенных вод. Концентрации элементов, как правило, выше в лизиметрических водах из всех горизонтов почв подкроновых пространств по сравнению с межкроновыми, при этом в почвенных водах еловых лесов концентрации соединений элементов значительно выше, чем в водахсосновых лесов. Многолетняя динамика концентраций тяжелых металлов и 
сульфатов в почвенных водах отличается высокой вариабельностью и демонстрируют тенденцию к снижению, что может свидетельствовать о постепенном снижении техногенной нагрузки. Однако анализ полученных данных и сопоставление с фоновыми значениями свидетельствует о существенном влиянии воздушного промышленного загрязнения на леса.

\section{Оценка критических уровней} воздействия на леса на основе состава атмосферных выпадений и почвенных вод

Оценка устойчивости почв к загрязняющим веществам основана на почвенно-экологических принципах (Глазовская, 1989, 1990, 1999). Почвы считаются загрязненными при накоплении в них загрязняющих веществ в количестве, представляющем опасность для живых организмов. Экспертные оценки загрязнения почв основаны на их внутренних свойствах: мощность горизонтов, содержание, состав и свойства гумуса, гранулометрический состав, емкость катионного обмена, биологическая активность почвы, содержание растворимых форм загрязняющих веществ и т.д. Уже более четверти века развивается другой подход, который связан с систематизацией почв и экосистем по степени их устойчивости к поллютантам установление критических нагрузок загрязняющих веществ. Идеи экологического нормирования на международном уровне нашли свое воплощение в разработке концепции критических нагрузок в рамках «Конвенции о трансграничном загрязнении воздуха на большие расстояния». В соответствии с этой Конвенцией, выбросы поллютантов должны быть сокращены до приемлемых (критических) выпадений или концентраций (Копцик, 2004).

Понятие «критическая нагрузка» подразумевает показатель, который характеризует максимальную величину воздействия одного или нескольких поллютантов на единицу площади ландшафта, ниже которого на современном уровне знаний не происходит существенных негативных процессов для конкретных чувствительных элементов среды (Nilsson, Greenfelt, 1988). Критические нагрузки (critical loads) рассчитываются с использованием химических индикаторов, или критических пределов (critical limits), определяющих вредное воздействие и пороговые значения. В атмосферных выпадениях (дождь и снег) обычно рассчитывают критическую нагрузку для определенного элемента, например для сульфатной серы (Korhola et al., 1999), азота (Waldner et al., 2007) или тяжелых металлов (Reinds et al., 2006). Для оценки процессов подкисления почв, которые могут негативно влиять на рост деревьев, предложен такой индикатор как молярное отношение суммы основных катионов (кальций, магний и калий) и алюминия в почвенных растворах (Sverdrup, 1993). При повышенных кислотных нагрузках почва постепенно истощается основными катионами, в основном кальцием $\left(\mathrm{Ca}^{2+}\right)$ и магнием $\left(\mathrm{Mg}^{2+}\right)$. При подкислении почв образуются токсичные формы алюминия. Повышенная концентрация таких форм Al в почвенном растворе может привести к ингибированию роста корней, повреждениям мелких корней и микоризы и, таким образом, снизить потребление питательных веществ и воды (Foy, 1988; Ulrich, 1983; Boudot et al., 1994; Godbold, Hüttermann, 1988; Godbold, Kettner, 1991; Godbold et al., 1988). Для оценки эвтрофикации, насыщения азотом, используют концентрации минерального азота в почвенных растворах. Увеличение выпадений $\mathrm{N}$ может вызвать эвтрофикацию почвы, а также интенсифицировать вымывание нитратов, что часто называют насыщением N (Aber et al., 1998; Gundersen, 1991). В целом результатом могут быть недостаток элементов питания и снижение скорости роста лесных растений. Повышенное вымывание нитратов связано с подкислением почвы, вызывающим постепенное снижение концентрации основных катионов в почвенных растворах с последующим увеличением концентраций Al.

В Швейцарии были проведены исследования (1999-2002 гг.) состава 
почвенных растворов на шести лесных участках, характеризующихся кислыми минеральными почвами для определения превышения критических нагрузок. Проведен анализ молярного отношения основных катионов к общему растворенному алюминию - $\mathrm{BC} / \mathrm{Al}_{\text {tot. }}$. Среднее соотношение $\mathrm{BC} / \mathrm{Al}_{\text {tot }}$ в почвенном растворе никогда не достигало критической величины в корневой зоне на всех участках за весь период наблюдения. Базовое соотношение $\mathrm{BC} / \mathrm{Al}$ в почвах значительно коррелировало с отношениями $\mathrm{BC} / \mathrm{Al}_{\text {tot }}$ В почвенном растворе. Почвенные растворы с самыми низкими отношениями $\mathrm{BC} / \mathrm{Al}_{\text {tot }}(\leq$ 2) обычно встречались в минеральных почвах с отношением BC/Al ниже 0,2. Химический состав почвенного раствора зависит от состава подстилающих слоев почвы. Почвенные растворы на 80 см имели значения $\mathrm{pH}$ и отношения $\mathrm{BC} / \mathrm{Al}_{\text {tot }}$ намного выше, чем ожидалось, поэтому рекомендовано учитывать это обстоятельство при расчетах критических нагрузок кислотности (Graf Pannatier et al., 2004).

$\mathrm{B}$ районе с выраженной морской импульверизацией и высоким уровнем выпадений азота в юго-западной части Ютландии, Дания, проводились исследования (с 1989 по 1999 гг.) по оценке пригодности показателя $\mathrm{BC} / \mathrm{Al}$ и отношений $\mathrm{Ca} / \mathrm{Al}$ в почвенном растворе в качестве химических критериев для расчетов критической нагрузки на лесные экосистемы. Выявлено, что уровни атмосферных выпадений в хвойных лесах на кислых почвах превышали показатели критической нагрузки для $\mathrm{N}$ в Дании. Интенсивное вымывание $\mathrm{N}$ из почв лесов, формируемых ситхинской елью (Picea sitchensis), указывало на высокий уровень насыщения N. Хотя в ельниках, выпадения $\mathrm{N}$ оказались выше уровня критических нагрузок, исследуемый участок еще не был насыщен $\mathrm{N}$, поскольку вымывание нитратов с почвенными водами было невелико. Буковые леса (Fagus sylvatica) отличались более широкими отношениямиВC/Al $1_{\text {tot }}$ почвенных водах, чем леса, формируемые ситхинской елью и елью обыкновенной (Picea abies) в 1989 г., но эти отношения постепенно приближались к 1 для лесов формируемых всеми тремя видами к 1999 г. Очень узкие отношения $\mathrm{Ca} /$ Altot и $\mathrm{BC} / \mathrm{Al}_{\text {tot }}$, наблюдаемые в этом исследовании, контрастируют с улучшением или неменяющимся состоянием древостоев. Это поставило под вопрос применимость этих соотношений в качестве химических критериев в районах с повышенным уровнем выпадений морских солей. Близость к морю и значительное поступление основных катионов в верхние слои почвы могут способствовать устойчивости лесов и преодолению дефицита питательных веществ в более глубоких слоях почвы (Hansen et al., 2007).

В Европе были проведены широкомасштабные исследования, направленные на изучение варьирования выпадений серы и азота, и превышения их критических нагрузок на площадках интенсивного мониторинга уровня II ICP Forests. Данные были получены с 2000 по 2005 годы на более чем 150 мониторинговых площадках. Выпадения аммония, нитратов и сульфатов под пологом леса выше, чем на открытых участках, также наблюдается сокращение выбросов серы и менее значительное сокращение выбросов азота в Европе. На исследуемых участках превышение критических нагрузок для серы было зафиксировано в меньшей степени, чем для азота. В осадках, прошедших сквозь древесный полог, наблюдается превышение критического уровня азота примерно на $2 / 3$ исследуемых участков. Самые высокие превышения встречаются в Нидерландах, Бельгии и на некоторых землях Германии, наименьшие в Соединенном Королевстве, в Фенноскандии, в Греции и в Альпах. Критические нагрузки были превышены на менее, чем на четверти участков, расположенных в основном в Нидерландах, на юге Швеции, на некоторых землях Германии и в Венгрии. Отмечается, что превышение критических нагрузок позволяет определить порог для определенных поллютантов, которые могут через некоторое нанести ущерб экосистеме. Поэтому для оценки реакции экосистем 
важно определить, достигнуты ли критические пределы (Lorenz, Granke, 2009).

В северной части Бельгии были проведены исследования химического состава атмосферных выпадений и почвенных растворов за семнадцатилетний

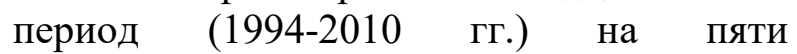
мониторинговых станциях с хвойными и лиственными биогеоценозами. В ходе исследования было выявлено, что отношения BC/Al были ниже критического уровня на трех участках на песчаных почвах с е низкой степенью насыщенности почв основаниями. Показатель кислотонейтрализующей способности в почве возрастал, но оставался отрицательным, указывая на то, что подкисление почвы продолжалось, так как начало восстановления было замедленно одновременным уменьшением выпадений основных катионов и краткосрочными процессами буферирования почвы. Критические пределы концентраций $\mathrm{N}$ в почвенном растворе, в значительной степени, были превышены в течение большей части года на всех глубинах на пяти участках (Verstraeten et al., 2012).

Еще одно широкомасштабное исследование в Европе было проведено с 2006 по 2009 гг., на более чем 200 мониторинговых площадях, целью которого было изучить взаимосвязь между превышением критических нагрузок и концентрацией неорганического азота, отношением основных катионов к алюминию в почвенных растворах, а также питательным статусом деревьев. Это исследование показало, что существуют различия в частоте превышения критических пределов для почвенного раствора между группами участков, классифицированных в соответствии с текущим превышением критических нагрузок, причем эти превышения, вероятно, сохраняются в течение нескольких десятилетий. Аналогичная дифференциация была обнаружена при оценке питательного статуса деревьев для групп, выделенных в соответствии с превышением критических пределов для почвенного раствора. Результаты подтверждают гипотезу о том, что эвтрофирование или подкисляющее воздействие выпадений неорганических соединений $\mathrm{N}$ и $\mathrm{S}$ может привести к дисбалансу в питании деревьев (Waldner et. al. 2015).

Оценки критических нагрузок на леса проводились и отечественными учеными. Например, с 1982 по 2003 гг. были проведены исследования состояния атмосферного воздуха и осадков Русской равнины. На ее обширной территории располагаются крупные целлюлознобумажные, металлургические, химические, нефтегазодобывающие и перерабатывающие предприятия. Их выбросы и сбросы негативно воздействуют на окружающую среду. В результате исследования было выявлено, что критические пределы по выпадениям серы были превышены на локальных участках в Ленинградской, Московской, Рязанской областях. По сумме выпадений азота уровень критических нагрузок был превышен примерно на половине площади ETP: в Северо-Западном, Северном и Центральном районах. В целом на исследованной площади ЕТР (3.2 млн. км²) уровни критических нагрузок по азоту превышены на площади 2.3 млн. км ${ }^{2}$, а по

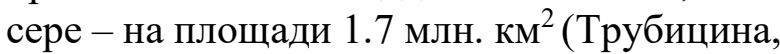
2008).

На Кольском полуострове была проведена оценка критических нагрузок кислотообразующих соединений серы и риска их избыточного поступления в экосистемы. В результате исследования было выявлено, что $58 \%$ площади Кольского полуострова занимают наиболее чувствительные экосистемы (северотаежные леса и криволесья на подзолах, a также тундровые и лесотундровые сообщества), для которых критические нагрузки серы не превышают 400 экв га ${ }^{-1}$ год ${ }^{-1}$. К устойчивым системам (от 500 до 600 экв га г $^{-1}$ год ${ }^{-1}$ ) относят горные тундры и леса, березовые криволесья и редколесья на подбурах и иллювиальногумусовых подзолах занимающие до 8\% площади полуострова. Наиболее устойчивые системы (более 700 экв га ${ }^{-1}$ год ${ }^{-1}$ ) занимают $7 \%$ площади, наряду с 
болотными сообществами включают в себя сосновые и еловые леса на иллювиальногумусовых подзолах. Зоны риска составляют более $20 \%$ Кольского полуострова - это обширные территории на северо-западе и в центре, которые находятся вблизи комбинатов «Североникель» и «Печенганикель» (Копцик и др., 2008).

В рамках одного из международных проектов ООО «Газпром-ВНИИГАЗ» была проведена оценка критических нагрузок подкисляющих и эвтрофирующих соединений для территории Венесуэлы в связи с планируемой интенсификацией газовой отрасли этой страны. Согласно расчетам экосистемы более чем $40 \%$ территории Венесуэлы имеют высокий потенциал устойчивости к кислотным выпадениям, в то же время экосистемы, формирующиеся на $10 \%$ площади, характеризуются пониженной устойчивостью к подкисляющим соединениям. Наименее устойчивыми, являются экосистемы горных лесов на маломощных кислых почвах, вдоль восточных границ Венесуэлы и в горной области Анд на западе страны. Повышенные и высокие уровни рисков эвтрофирования экосистем выявлены на ограниченной площади (примерно 0.2 и $0.8 \%$ соответственно) и характерны для территорий, расположенных в зонах воздействия промышленных центров Венесуэлы (на западе и северо-востоке страны). Данное исследование совместного использования методологий риска и критических нагрузок показало перспективность данного подхода для решения практических задач экологической и природоохранной деятельности предприятий (Припутина, Башкин, 2012).

В обзоре подходов к оценке экологического состояния и нормированию качества почв (Коновалов и др., 2017) была предпринята попытка осветить российские и зарубежные подходы к данной проблеме. Отмечается, что при оценке экологического состояния почв очень важно разграничивать между собой различные виды почвенной деградации: физическую, химическую, микробиологическую и комплексную. В России преимущественно используют санитарно-гигиенический подход, в котором действует концепция предельно допустимых концентраций (ПДК), то есть такое содержание химических элементов в среде, которое в течение длительного времени не вызывает негативного (прямого или косвенного) влияния на здоровье человека. Помимо этого, ПДК характеризуют лишь степень антропогенных нарушений в экосистемах, если существующий уровень концентраций поллютантов ниже ПДК, считается, что допустимо дальнейшее техногенное воздействие на данную территорию, а при превышении нагрузка должна быть прекращена. Однако, ответов на вопросы, какой уровень поступления в экосистему загрязняющих веществ допустим, чтобы не нарушалось функционирование природных систем и насколько воздействие должно быть снижено для прекращения негативного изменения в окружающей среде, при таком подходе получить невозможно н (Башкин и др., 2005). Поэтому данный подход имеет существенные недостатки и для развития системы экологического нормирования необходимо развивать другие подходы. Например - биогеохимический и статистический подходы, а также экосистемное нормирование. За рубежом получает распространение подход, основанный на оценке экологических рисков, в который входит концепция критических нагрузок. В России его применение также может оказаться эффективным, что демонстрируется в работах В.Н. Башкина (2004), Г.Н. Копцик и С.В. Копцик (2008) и др.

Таким образом, зарубежными, и отечественными авторами, разработаны различные методы оценки и меры по сокращению влияния воздушного промышленного загрязнения на лесные экосистемы. Следует отметить, что при оценке критических нагрузок на леса редко учитывается влияние микромозаичной структуры биогеоценоза (Ершов и др., 2020). На примере лесов Мурманской области выявлено, что выпадения тяжелых металлов и сульфатов в атмосферных 
выпадениях превышали годовые критические уровни (до 4 раз) уже в фоновых условиях, но только в подкроновых пространствах. Наиболее высокие превышения наблюдаются в дефолиирующих лесах и техногенных редколесьях, что особенно ярко выражено в подкроновых пространствах еловых лесов, в которых максимальные превышения уровня критических нагрузок выпадений сульфатов - до 7 раз и тяжелых металлов 600 раз. Проведена оценка превышений критических уровней в почвенных водах с использованием международных показателей: отношение основных катионов к алюминию $(\mathrm{BC} / \mathrm{Al})$ и концентрации минерального азота в почвенном растворе (Nmin) (Ершов и др., 2019). Отношение основных катионов к алюминию на всех стадиях дигрессии в еловых и сосновых лесах значительно превышает критические значения, что можно объяснить богатством почвообразующих пород и почв региона исследований основными катионами.

\section{СПИСОК ЛИТЕРАТУРЫ}

Ананьева С.И., Белова Е.А., Бульчев А.Г. и $\partial p . /$ Кольская горно-металлургическая компания (промышленные площадки «Никель» и «Заполярный»): влияние на наземные экосистемы. Под общ ред. О.

А. Хлебосоловой. Рязань: НП «Голос губернии». 2012. 92 с.

Артемкина Н.А., Горбачева Т.Т., Лукина $H . B$. Низкомолекулярные органические кислоты в почвенных водах лесов Кольского полуострова // Лесоведение. 2008. № 6. C. 37-44.

Артемкина Н.А., Горбачева Т.Т., Лукина H.B. Низкомолекулярные органические кислоты в почвенных водах лесов Кольского полуострова в условиях воздушного промышленного загрязнения // Лесоведение. 2011. № 4. С. 21-29.

Арчегова И.Б., Кузнецова Е.Г. Влияние древесных растений на химический состав атмосферных осадков в процессе восстановления среднетаежных лесов // Лесоведение. 2011. № 3. С. 34-43.

Бахмет О.Н., Федореи Н.Г., Ласточкина B.Г. Химический состав атмосферных
Критический уровень минерального азота превышен на всех стадиях дигрессии, в подкроновых пространствах превышения, как правило, выше, чем в межкроновых.

Анализ работ позволяет заключить, что состав атмосферных выпадений и почвенных вод необходимо проводить с учетом внутри- и межбиогеоценоточеской мозаичности лесного покрова, что позволит проводить раннюю диагностику техногенного загрязнения лесов. Для оценки и прогнозирования динамики биогеохимических циклов в лесных экосистемах необходимы оценки многолетних изменений состава и свойств атмосферных выпадений и почвенных вод. Для определения превышения критических нагрузок на лесные экосистемы целесообразно использовать концепцию критических нагрузок.

\section{БЛАГОДАРНОСТИ}

Исследование выполнено в рамках темы государственного задания КНЦ РАН № AAAA-A18-118021490070-5

осадков и почвенных вод Карелии. Петрозаводск: Карельский научный центр РАН. 2011. 34 с.

Башкин В.Н., Курбатов А.А., Припутина И.В. Показатели критических нагрузок вместо ПДК // Экология и промышленность России. 2005. № 8. С. 25-29.

Башкин В.Н., Курбатова А.С., Савин Д.С. Методологические основы оценки критических нагрузок поллютантов на городские экосистемы. М.: НИиПИ Экологии города, 2004.

Василенко В.Н., Назаров И.М., Фридман Ш.Д. Исследование дальнего переноса сульфатов в Советской Арктике по загрязнению снежного покрова // Метеорология и гидрология. 1985. № 4. C. 114-117.

Вернадский В.И. Избранные сочинения. М.: Изд-во АН СССР. 1960. 420 с.

Воеводова 3.И. Возможность определения влияния загрязнения атмосферы на водные ресурсы путем отбора проб снега. В кн.: Влияние хозяйственной деятельности человека на водные 
ресурсы Коми АССР. Сыктывкар, 1979. C. 80-88.

Воейков А.И. Влияние снеговой поверхности на климат / Избр. соч. Л.; М., Изд-во АН СССР. 1949. Т. 2. 531 с.

Воробейчик Е.Л., Кайгородова С.Ю. Многолетняя динамика содержания тяжелых металлов в верхних горизонтах почв в районе воздействия медеплавильного завода в период сокращения объемов его выбросов // Почвоведение. 2017. № 8. С. 1009-1024.

Глазовская М.А. Опыт классификации почв мира по устойчивости к техногенным кислотным воздействиям

Почвоведение. 1990. № 9. С. 82-96.

Глазовская М.А. Принципы классификации почв по опасности их загрязнения тяжелыми металлами // Биол. Науки. 1989. № 9. С. 38-47.

Глазовская М.А. Проблемы и методы оценки эколого-геохимической устойчивости почв и почвенного покрова к техногенным воздействиям // Почвоведение. 1999. № 1. С. 114-124.

Глазовский Н.Ф., Злобина А.И., Учватов B.П. Химический состав снежного покрова некоторых районов Верхнеокского бассейна // Региональный экологический мониторинг (На примере Верхнеокского бассейна). М.: Наука. 1983. С. 67-86.

Даувальтер В.А., Даувальтер М.В., Салтан H.В., Семенов Е.Н. Влияние выбросов горно-металлургического комбината на химический состав атмосферных выпадений (Мончегорский полигон) // Геоэкология. 2009. № 3. С. 228-240.

Демаков Ю.П., Исаев В.Л. Влияние аэрального поступления веществ на их круговорот в лесных экосистемах // Вестник Поволжского государственного технологического университета. Серия «Лес. Экология. Природопользование». Йошкар-Ола. 2015. № 1. С.66-86.

Дерябина Л.В., Перетыкин А.А.Зообентос как индикатор экологического состояния природной области Шершнёвского водохранилищав июле-августе 20122013 годов // Вестник Челябинского государственного университета. 2015. № 21. C. 99-102.
Евдокимова Г.А., Кисльх Е.Е., Мозгова Н.П. Биологическая активность почв в условиях аэротехногенного загрязнения на Крайнем Севере. Л. 1984. 121с.

Ершов В.В., Лукина Н.В., Данилова М.А., Исаева Л.Г., Сухарева Т.А., Смирнов В.Э. Оценка состава дождевых выпадений в хвойных лесах на северном пределе распространения при аэротехногенном загрязнении // Экология. 2020. № 4. С. 265-274.

Ершов В.В., Лукина Н.В., Орлова М.А., Исаева Л.Г., Смирнов В.Э., Горбачева T.T. Оценка динамики состава почвенных вод северотаежных лесов при снижении аэротехногенного загрязнения выбросами медно-никелевого комбината // Сибирский экологический журнал. 2019. № 1. С. 119-132.

Зайцева A.O. Техногенные источники химического загрязнения атмосферы Красноярского края // Актуальные проблемы авиации и космонавтики. 2016. T. 1. № 12. С. 956-958.

Карабань Р.Т., Назаров И.М., Руднева И.А., Сисигина Т.И. О накоплении никеля в почве и древесной растительности лесонасаждений, произрастающих вокруг предприятий цветной металлургии // Миграция загрязняющих веществ в почвах и сопредельных средах. Л., 1985. С. 109-117.

Карпачевский Л.О. Лес и лесные почвы. М.: Лесная промышленность. 1981. 264 с.

Карпухин А.И., Яшин И.М., Черников В.А. Формирование и миграция комплексов водорастворимых органических веществ с ионами тяжелых металлов в таежных ландшафтах Европейского Севера // Известия ТСХА. 1993. Вып. 2. С. 107126.

Кислотные осадки и лесные почвы / Под ред. Никонова В.В. и Г.Н. Копцик. Апатиты: изд-воКНЦ РАН. 1999. 320 с.

Клюев Н.Н., Яковенко Л.М. «Грязные» города России: факторы, определяющие загрязнение атмосферного воздуха // Вестник Российского университета дружбы народов. Серия экология и безопасность. 2018. Т. 26. № 2. С. 237250. 
Ковда B.A. Биогеохимия почвенного покрова. Издательство: Наука. 1985. 264 c.

Коновалов А.Г., Рисник Д.В., Левич А.П., Фурсова П.В. Обзор подходов к оценке экологического состояния и нормированию качества почв // Междисциплинарный научный и прикладной журнал «Биосфера» 2017. Т. 9. № 3. С. 214-229.

Копанев И.Д. Климатические аспекты изучения снежного покрова / Л., Гидрометеоиздат, 1982. 239 с.

Копиик Г.Н. Устойчивость лесных почв к атмосферному загрязнении // М.: Лесоведение. 2004. № 4. С. 61-71

Копцик Г.Н., Лукина Н.В., Смирнова И.Е. Влияние атмосферного промышленного загрязнения на состав почвенных растворов подзолов // Почвоведение. 2007. № 2. C. 223-234.

Копџик С.В., Копџик Г.Н., Алябина И.О. Оценка риска избыточного поступления соединений серы в наземные экосистемы Кольского полуострова // Экология. 2008. № 5. С. 347-356.

Кравченко И.Ю. Химический состав почвенных вод хвойных лесов средней тайги Карелии // В сборнике: Биодиагностика состояния природных и природно-техногенных систем Материалы XIV Всероссийской научнопрактической конференции с международным участием. 2016. С. 330335.

Kудреватых И.Ю. Оценка взаимосвязи между атмосферным выпадением минерального азота и растительностью в лесных экосистемах // Экология. Известия РАН. Серия биологическая. 2017. № 2. С. 181-189.

Курпатов С.В., Михайлуи А.П., Иванова О.Ю. Формирование техногенных нагрузок химического загрязнения атмосферного воздуха в современных условиях развития производительных сил в Красноярском крае // Российский медико-биологический вестник имени академика И.П. Павлова. 2016. Т. 24. № 4. С. 17-24.

Лукина Н.В., Никонов В.В. Биогеохимические циклы в лесах Севера в условиях аэротехногенного загрязнения. Ч. 1. Апатиты: Изд-во КНЦ PAH. 1996. $216 \mathrm{c}$.

Лукина Н.В., Никонов В.В. Питательный режим лесов северной тайги. Апатиты: Изд-во Кол. науч. центра РАН, 1998. $316 \mathrm{c}$.

Лукина Н.В., Полянская Л.М., Орлова М.А. / Питательный режим почв северотаежных лесов. М.: Наука, 2008. 342 c.

Мартынюк А.А., Дороничева Е.В., Рыкова T.B. Изменение химического состава природных осадков под пологом сосновых насаждений в условиях техногенного загрязнения среды // Лісовий журнал. 2011. № 1. С. 8-11.

Марунич С.В., Буров А.С., Кузнечова Ю.Н., Недогарко И.В. Трансформация химического состава атмосферных осадков пологом древостоя южнотаежных лесов // Известия РАН. Серия географическая. 2006. № 4. С. 52-57.

Медведев Л.В., Шитикова Т.Е., Алексеенко B.A. Трансформация жидких атмосферных осадков древостоями южной тайги (на примере Валдая) // Структура и функционирование экосистем южной тайги. М. 1986. С. 2655.

Морозова Р.М., Куликова В.К. Роль атмосферных осадков в круговороте азота и зольных элементов в еловых лесах Карелии // Почвенные исследования в Карелии. Петрозаводск: Ин-т леса КФ АН СССР. 1974. C. 143-161.

Мотузова Г.В. Почвенно-химический экологический мониторинг. М.: МГУ, $2001.85 \mathrm{c}$.

Мотузова Г.В., Барсова Н.Ю., Карпова Е.A., Кочарян А.Г. Состав лизиметрических вод почв Верхневолжских ландшафтов// Почвоведение. 2009. № 2. С.1-9.

Никонов В.В., Лукина Н.В., Безель В.С и др. Рассеянные элементы в бореальных лесах / Отв. ред. Исаев А. С. М.: Наука, 2004. $616 \mathrm{c}$.

Никонов В.В., Лукина Н.В. Влияние ели и сосны на кислотность и состав атмосферных выпадений в северо- 
таежных лесах индустриально развитого региона // Экология. 2000. № 2. С. 97105.

Оболкин В.А., Ходжер Т.В., Анохин Ю.А. и $\partial p$. Кислотность атмосферных выпадений в регионе Байкала // Метеорология и гидрология, 1991. № 1. C. 55-60.

Поздняков Л.К. О роли осадков, проникающих под полог леса, в процессе обмена веществ между лесом и почвой // Доклады АН СССР. 1956. Т. 107. № 5. С. 753-756.

Припутина И.В., Башкин В.Н. Экологические риски в связи с техногенным загрязнением окружающей среды: анализ подходов и методов оценки // Проблемы анализа риска. 2012. Т. 9. № 5. С. 4-25.

Пристова T.A. Влияние древесного полога лиственно-хвойного насаждения на химический состав осадков // Лесоведение. 2005. № 5. С. 49-55.

Пристова, Т.А, Василевич М.И. Химический состав снежного покрова в лесных экосистемах в зоне аэротехногенного влияния целлюлознобумажного производства (ЦБП) // Известия Самарского научного центра Российской академии наук. Самара: Издво Самарского научного центра РАН, 2010. T. 12. № 1 (9). C. 2313-2316.

Пьявченко Н.И., Сиберева З.А. О роли атмосферной пыли в питании болот // Доклады АН СССР. 1959. Т. 124. № 2. С. 414-417.

Раткин H.E. Количественная оценка аэротехногенного потока вещества на подстилающую поверхность расчетным методом // Вестник МГТУ.2000. Т. 3. № 1. C. 145-164.

Раткин Н.Е., Асминг В.Э., Кошкин В.В. Влияние природных локальных факторов на загрязнение снежного покрова (на примере Печенгского района) // Вестник МГТУ. 1988. Т. 1. № 3. C. 151-160.

Раудина Т.В. Почвенный раствор: от классических представлений к современным понятиям // В сборнике: Отражение био-, гео-, антропосферных взаимодействий в почвах и почвенном покрове сборник материалов V Международной научной конференции, посвященной 85-летию кафедры почвоведения и экологии почв ТГУ. Министерство образования и науки Российской Федерации, Томский государственный университет, Общество почвоведов им. В.В. Докучаева, Институт почвоведения и агрохимии $\mathrm{CO}$ PAH, Институт мониторинга климатических и экологических систем. 2015. С. 87-93.

Робакидзе Е.А., Торлопова Н.В., Бобкова K.C. Химический состав жидких атмосферных осадков в старовозрастных ельниках средней тайги // Геохимия. 2013. № 1. С. 72-83.

Poде А.A. Почвоведение. М.: Гослесбумиздат. 1955.524 с.

Смит У. Х. Лес и атмосфера. М.: Прогресс. $1985.430 \mathrm{c}$.

Султанбаева Р.Р., Копџик Г.Н., Смирнова И.Е., Копиик С.В. Поступление и миграция растворимого органического углерода в почвах лесных экосистем подзоны широколиственно-хвойных лесов // Вестник Московского университета. Серия 17: Почвоведение. 2015. № 4. C. 37-42.

Тентюков М.П. Особенности формирования загрязнения снежного покрова: морозное конденсирование техногенных эмиссий (на примере районов нефтедобычи в большеземельской тундре) // Криосфера земли. 2007. Т. 11. № 4. С. 31-41.

Трубицина О.П. Анализ геоэкологического состояния атмосферного воздуха и осадков севера Русской равнины по данным мониторинга // Вестник Поморского университета. Серия: Естественные науки. 2008. № 3. С. 35-42.

Тяжелье металль в окружающей среде / под ред. Л.В. Осадчук, А.И. Сысо. М.: Изд-во МГУ, 1980. Выпуск 2. 80 с.

Учватов В.П., Глазовский Н.Ф. Трансформация химического состава природных вод в лесном ландшафте как показатель его биогеохимического функционирования // Известия АН СССР. Сер. Геогр. 1984. № 1. С. 101-109. 
Хрусталева М.А. Экогеохимия моренных ландшафтов центра Русской равнины / М.: Технополиграфцентр, 2002. 315 с.

Цветков В.Ф., Цветков И.В. Промышленное загрязнение окружающей среды и лес. Архангельск: ИПЦ САФУ. 2012. 312c.

Шепель К.C. Геоэкологическая оценка загрязнения почв в районе расположения предприятия горно-металлургического комплекса Урала // Проблемы недропользования. 2019. № 2. С. 171176.

Шильиова Г.В. Роль сосновых биогеоценозов заповедника «Кивач» в формировании кислотности и состава природных вод // Труды Карельского научного центра РАН. Выпуск 10. Петрозаводск. 2006. С. 173-179.

Ярмишко В.T. Оценка состояния подземных органов растений в условиях промышленного загрязнения // Влияние промышленных предприятий на окружающую среду: Тез. докл. на Всесоюз. Школе. 4-8 декабря. Звенигород. Пущино. 1984. С. 230-231.

Ярмишко В.T., Ярмишко М.А. Влияние пожаров и атмосферного загрязнения на структуру и продуктивность напочвенного покрова и травянокустарничкового яруса сосновых лесов на европейском севере России // Растительные ресурсы. 2002. Т. 38. Вып. 2. C. 40-54.

Aber J.D., McDowell W., Nadelhoffer K.J. et al. Nitrogen saturation in temperate forest ecosystems // BioScience.1998. V. 48. P. 921-934.

Balestrini R., Arisci S., Brizzio M.C., Mosello R., Rogora M., TagliaferriA. Dry deposition of particles and canopy exchange: comparison of wet, bulk and throughfall deposition at five forest sites in Italy // Atmospheric Environment. 2007. Vol. 41. P. 745-756.

Boudot J.P., Becquer T., Merlet D., Rouiller J. Aluminum toxicity in declining forests: A general overview with a seasonal assessment in a silver fir forest in the Vosges mountains (France) // Annales des Sciences Forestieres. 1994. V. 51. P. 27-51.
De Vries W., Reinds G.J., van Kerkvoorde M.A., Hendriks C.M.A., Leeters E.E.J.M., Gross C.P., Voogd J.C.H, Vel E.M. Intensive Monitoring of Forest Ecosystems in Europe. Technical Report 2000. UN/ECE, EC, Forest Intensive Monitoring Coordinating Institute.

De Vries W, Reinds G.J, Vel E. Intensive monitoring of forest ecosystems in Europe 2: atmospheric deposition and its impacts on soil solution chemistry // Forest Ecology and Management. 2003. Vol. 174. P. 97115.

De Vries, W., Dobbertin M.H., Solberg S., van Dobben H.F., Schaub M. Impacts of acid deposition, ozone exposure and weather condition on forest ecosystem in Europe: an overview // Plant Soil. 2014. 380. P. 1-45.

Derome J., Lukina N. Interaction between environmental pollution and landcover/land-use change in Arctic areas / Eurasian Arctic land cover and land use in a changing climate (Gutman G., Reissell A., eds.). Netherlands: Springer, 2010. P. 269290.

Engardt M., Simpson D., Schwikowski M., Granat L. Deposition of sulphur and nitrogen in Europe 1900-2050. Model calculations and comparison to historical observations // Tellus B: Chemical and Physical Meteorology. 2017. Vol. 69. Article 1328945.

Ershov V.V., Lukina N.V., Orlova M.A., Zukert N.V. Dynamics of Snowmelt Water Composition in Conifer Forests Exposed to airborne industrial Pollution // Rus. J. of Ecology. 2016. Vol. 47. No. 1. P. 46-52.

Ferm M., Granat L., Engardt M., Pihl Karlsson G., Danielsson H., Karlsson P.E., Hansen $K$. Wet deposition of ammonium, nitrate and non-sea-salt sulphate in Sweden 1955 through 2017 // Atmospheric Environment: X. 2019. Vol. 2. P. 1-10.

Ferretti M., Beuker E., Calatayud V., Canullo R., Dobbertin M., Eichhorn J., Neumann M., Roskams P., Schaub M. Data quality in field surveys: Methods and results for tree condition, phenology, growth, plant diversity and foliar injury due to ozone / Forest Monitoring. Ferretti M., Richard M. (eds.). Edition: 1. Chapter: 21. UK: Elsevier, 2013. P. 397-414. 
Foy C.D. Plant adaptation to acid, aluminiumtoxic soils // Communications in Soil Science and Plant Analysis. 1988. Vol. 19. P. 959-987.

Godbold D.L., Hüttermann A. Aluminium toxicity and forest decline // Proceedings of the National Academy of Sciences of the United States of America. 1988. Vol. 85. P. 3888-3892.

Godbold D.L., Kettner C. Use of root length elongation studies to determine aluminium and lead toxicity in Picea abies seedlings // Journal of Plant Physiology. 1991. Vol. 138. P. 231-235.

Godbold D.L., Dictus K., Hüttermann A. Influence of aluminum and nitrate on root growth and mineral nutrition of Norway spruce (Picea abies) seedlings // Canadian Journal of Forest Research. 1988. Vol. 18. P. 1167-1171.

Graf Pannatier E., Walthert L., Blaser P. Soil solution chemistry in acid forest soils: Are the BC: Al ratios as critical as expected in Switzerland? // Journal of Plant Nutrition and Soil Science. Vol. 164. P. 160-168.

Gundersen P., Sevel L., Christiansen J.R. et al. Do indicators of nitrogen retention and leaching differ between coniferous and broadleaved forests in Denmark? // Forest Ecology and Management. 2009. Vol. 258. P. 1137-1146.

Gundersen $P$. Nitrogen deposition and the forest nitrogen cycle: Role of denitrification // Forest Ecology and Management 1991. Vol. 44. P. 15-28.

Hansen K. Vesterdal L., Bastrup-Birk A., BilleHansen J. Are Indicators for Critical Load Exceedance Related to Forest Condition? // Water, Air \& Soil Pollution. Vol. 183. P. 293-308

Helmisaari H.S., Mälkönen E. Acidity and nutrient content of throughfall and soil leachate in three Pinus sylvestris stands // Scandinav. J. of Forest Research. 1989. Vol. 4. Issue 1-4. P. 13-28.

Herrmann M., Pust J., Pott R. The chemical composition of throughfall beneath oak, birch and pine canopies in Northwest Germany // Plant Ecology. 2006. Vol. 184. P. 273-285.

IPCC (2007) Climate Change 2007: The Physical Science Basis. Contribution of
Working Group I to the Fourth Assessment Report of the Intergovernmental Panel on Climate Change. Cambridge University Press, Cambridge, United Kingdom and New York, NY, USA.

Jakovljevic T., Marchetto A., Lovreškov L. et al. Assessment of Atmospheric Deposition and Vitality Indicators in Mediterranean Forest Ecosystems // Sustainability. 2019. Vol. 11. P. 1-23.

Johnson J., Graf Pannatier E., Carnicelli S. et al. The response of soil solution chemistry in European forests to decreasing acid deposition // Global Change Biology. 2018. Vol. 24. P. 3603-3619.

Kashulina G., Caritat P., Reimann C. Snow and rain chemistry around the "Severonikel" industrial complex, NW Russia: Current status and retrospective analysis // Atmospheric Environment. 2014. Vol. 89. P. 672-682.

Korhola A., Weckstrom J., Nyman M. Predicting the long-term acidification trends in small subarctic lakes using diatoms // Journal of Applied Ecology. 1999. Vol. 36. P. 1021-1034.

Kowalska A., Astel A., Boczoń A., Polkowska $\dot{Z}$. Atmospheric deposition in coniferous and deciduous tree stands in Poland // Atmospheric Environment. 2016. Vol. 133. P. 145-155.

Kristensen H.L., Gundersen P., Callesen I., Reinds G.J. Throughfall nitrogen deposition has different impacts on soil solution nitrate concentration in European coniferous and deciduous forests // Ecosystems. 2004. Vol. 7. P. 180-192.

Lorenz M., Granke O. Deposition measurements and critical loads calculations: monitoring data, results and perspective // Forest - Biogeosciences and Forestry. Vol. 2. P. 11-14.

Lorenz $\quad M$. International co-operative programme on assessment and monitoring of air pollution effects on forests - ICP forests // Water Air Soil Pollut. 1995. Vol. 85. P. 1221-1226.

Lorenz M., Becher G. Forest Condition in Europe, 2012 Technical Report of ICP Forests. Work Report of the Thünen Institute for World Forestry 2012/1. ICP Forests, Hamburg, 2012. p. 159. 
Lukina N.V., Ershov V.V., Gorbacheva T.T., Orlova M.A., Isaeva L.G., Teben'kova D.N. Assessment of soil water composition in the northern taiga coniferous forests of background territories in the industrially developed region // Eurasian Soil Science. 2018. Vol. 51. No. 3. P. 285-297.

Lukina N.V., Nikonov V.V. Degradational succession of forest ecosystems in the surroundings of $\mathrm{Cu}-\mathrm{Ni}$ smelter in theKola Peninsula // Proceedings of 28th Annual Meeting. Sudbury, Ontario, 2003 [CDROM].

Maas R., Grennfelt P. Towards Cleaner Air. Scientific Assessment Report 2016. EMEP Steering Body and Working Group on Effects of the Convention on Long-Range Transboundary Air Pollution. 2016. p. 50.

Matzner E. Meiwes K.J. Long-term development of element fluxes with bulk precipitation and throughfall in two German forests // Journal of Environmental Quality Abstract. 1994. Vol. 23. P. 162-166.

Nilsson J., Grennfelt P. Critical loads for Sulphur and nitrogen // Miljorapport. 1988. p. 418

Pascaud A., Sauvage S., Coddeville P., Nicolas M., Croisé L., Mezdour A., Probst A. Contrasted spatial and long-term trends in precipitation chemistry and deposition fluxes at rural stations in France // Atmospheric Environment. 2016. Vol. 146. P. 28-43.

Pomeroy J.W., Davies T.D., Jones H.G. et al. Transformations of snow chemistry in the boreal forest: accumulation and volatilization // Hydrol. Process. 1999. Vol.13. P. 2257-2273.

Reinds G.J., Groenenberg J.E., Vrieset W. Critical Loads of copper, nickel, zinc, arsenic, chromium and selenium for terrestrial ecosystems at a European scale // Wageningen, Alterra. 2006. P. 46.

Sawicka K., Monteith D.T., Vanguelova E.I., Wade A.J. \& Clark J.M. Fine-scale temporal characterization of trends in soil water dissolved organic carbon and potential drivers // Ecological Indicators. 2016.Vol. 68. P. 36-51.

Schöpp W, Posch M, Mylona S, Johansson M. Long-term development of acid deposition (1880-2030) in sensitive freshwater regions in Europ // Hydrol Earth Syst Sci. 2003. pp. 436-446.

Svedrup $H$., Warfvinge $P$. Effect of soil acidification on the growth of trees and plants as expressed by the $(\mathrm{Ca}+\mathrm{Mg}+\mathrm{K}) / \mathrm{Al}$ ratio // Reports in Environmental Engineering and Ecology. 1993. Vol. 2. P. 123.

Thimonier A., Schmitt M., Waldner P., Rihm B. Atmospheric deposition on Swiss Longterm forest ecosystem research (LWF) plots // Environmental Monitoring and Assessment. 2005. V. 104. P. 81-118.

Thimonier A. Measurement of atmospheric deposition under forest canopies: Some recommendations for equipment and sampling design // Environmental Monitoring and Assessment. 1998. Vol. 52. P. 353-387.

van Dobben, H., De Vries W. Relation between forest vegetation, atmospheric deposition and site conditions at regional and European scales // Environmental Pollution. Vol. 158. P. 921-933.

Vanguelova E.I., Benham S., Pitman R. et al. Chemical fluxes in time through forest ecosystems in the UK - Soil response to pollution recovery // Environmental Pollution. Vo. 158. P. 1857-1869.

Verstraeten A., Neirynck J., Genouw G., Cools $N$., Roskmans P., Hens M. Impact of declining atmospheric deposition on forest soil solution chemistry in Flanders, Belgium // Atmospheric Environment. 2012. Vol. 62. P. 50-63.

Waldner P., Thimonier A., Graf Pannatier E. et al. Exceedance of critical loads and of critical limits impacts tree // Annals of Forest Science. 2015. Vol. 72. P. 929-939.

Waldner P., Schaub M., Graf Pannatier E., Schmitt M., Thimonier A., Walthert L. Atmospheric Deposition and Ozone Levels in Swiss Forests: Are Critical Values Exceeded? // Environmental Monitoring and Assessment. 2007. Vol. 128. P. 5-17.

\section{REFERENCES}

Aber J.D., McDowell W., Nadelhoffer K.J. et al., Nitrogen saturation in temperate forest ecosystems, BioScience, 1998, Vol. 48, pp. 921-934.

Anan'eva S.I., Belova E.A., Bulychev A.G. et al., Kol'skaja gorno-metallurgicheskaja 
kompanija (promyshlennye ploshhadki «Nikel'» $i$ «Zapoljarnyj»): vlijanie na nazemnye jekosistemy (Kola mining and metallurgical company (Nickel and Zapolyarny industrial sites): impact on terrestrial ecosystems), Rjazan': NP "Golos gubernii", 2012, $92 \mathrm{p}$.

Archegova I.B., Kuznecova E.G. Vlijanie drevesnyh rastenij na himicheskij sostav atmosfernyh osadkov $\mathrm{v}$ processe vosstanovlenija srednetaezhnyh lesov (The influence of woody plants on the chemical composition of precipitation during the restoration of mid-taiga forests), Lesovedenie, 2011, No 3, pp. 34-43.

Artemkina N.A., Gorbacheva T.T., Lukina N.V., Nizkomolekuljarnye organicheskie kisloty $\mathrm{V}$ pochvennyh vodah lesov Kol'skogo poluostrova (Low molecular weight organic acids in the soil waters of forests of the Kola Peninsula), Lesovedenie, 2008, No 6, pp. 37-44.

Artemkina N.A., Gorbacheva T.T., Lukina N.V., Nizkomolekuljarnye organicheskie kisloty $\mathrm{V}$ pochvennyh vodah lesov Kol'skogo poluostrova $\mathrm{V}$ uslovijah vozdushnogo promyshlennogo zagrjaznenija (Low molecular weight organic acids in the soil waters of the forests of the Kola Peninsula under industrial air pollution), Lesovedenie, 2011, No 4, pp. 2129.

Bahmet O.N., Fedorec N.G., Lastochkina V.G., Himicheskij sostav atmosfernyh osadkov $i$ pochvennyh vod Karelii, Petrozavodsk: Karel'skij nauchnyj centr RAN, 2011, 34 p.

Balestrini R., Arisci S., Brizzio M.C., Mosello R., Rogora M., Tagliaferri A., Dry deposition of particles and canopy exchange: comparison of wet, bulk and throughfall deposition at five forest sites in Italy, Atmospheric Environment, 2007, Vol. 41, pp. 745-756.

Bashkin V.N., Kurbatov A.A., Priputina I.V. Pokazateli kriticheskih nagruzok vmesto PDK (Indicators of critical loads instead of MPC), Jekologija i promyshlennost' Rossii, 2005, No 8, pp. 25-29.

Bashkin V.N., Kurbatova A.S., Savin D.S. Metodologicheskie osnovy ocenki kriticheskih nagruzok polljutantov na gorodskie jekosistemy (Methodological basis for assessing the critical loads of pollutants on urban ecosystems), Moscow: NIiPI Jekologii goroda, 2004.

Boudot J.P., Becquer T., Merlet D., Rouiller J., Aluminum toxicity in declining forests: A general overview with a seasonal assessment in a silver fir forest in the Vosges mountains (France), Annales des Sciences Forestieres, 1994, Vol. 51, pp. 2751.

Cvetkov V.F., Cvetkov I.V., Promyshlennoe zagrjaznenie okruzhajushhej sredy $i$ les (Industrial pollution and forest), Arhangel'sk: IPC SAFU, 2012, 312 p.

Dauval'ter V.A., Dauval'ter M.V., Saltan N.V., Semenov E.N., Vlijanie vybrosov gornometallurgicheskogo kombinata na himicheskij sostav atmosfernyh vypadenij (Monchegorskij poligon) (Influence of emissions from a mining and smelting plant on the chemical composition of atmospheric deposition (Monchegorsk test site), Geojekologija, 2009, No 3, pp. 228240.

De Vries W, Reinds G.J, Vel E., Intensive monitoring of forest ecosystems in Europe 2: atmospheric deposition and its impacts on soil solution chemistry, Forest Ecology and Management, 2003, Vol. 174, pp. 97115.

De Vries W., Reinds G.J., van Kerkvoorde M.A., Hendriks C.M.A., Leeters E.E.J.M., Gross C.P., Voogd J.C.H., Vel E.M., Intensive Monitoring of Forest Ecosystems in Europe, Technical Report 2000, UN/ECE, EC, Forest Intensive Monitoring Coordinating Institute.

De Vries, W., Dobbertin M.H., Solberg S., van Dobben H.F., Schaub M., Impacts of acid deposition, ozone exposure and weather condition on forest ecosystem in Europe: an overview, Plant Soil, 2014, 380, pp. 1-45.

Demakov Ju.P., Isaev V.L., Vlijanie ajeral'nogo postuplenija veshhestv na ih krugovorot $\mathrm{v}$ lesnyh jekosistemah (The effect of aerial intake of substances on their cycle in forest ecosystems), Vestnik Povolzhskogo gosudarstvennogo tehnologicheskogo universiteta. Serija "Les. Jekologija. Prirodopol'zovanie", Joshkar-Ola, 2015, No 1, pp. 66-86. 
Derjabina L.V., Peretykin A.A., Zoobentos kak indikator jekologicheskogo sostojanija prirodnoj oblasti Shershnjovskogo vodohranilishha v ijule-avguste 2012-2013 godov (Zoobenthos as an indicator of the ecological state of the natural area of the Shershnevsky reservoir in July-August 2012-2013), Vestnik Cheljabinskogo gosudarstvennogo universiteta, 2015, No 21, pp. 99-102.

Derome J., Lukina N., Interaction between environmental pollution and landcover/land-use change in Arctic areas, Eurasian Arctic land cover and land use in a changing climate (Gutman G., Reissell A., eds.), Netherlands: Springer, 2010, pp. 269-290.

Engardt M., Simpson D., Schwikowski M., Granat L., Deposition of sulphur and nitrogen in Europe 1900-2050. Model calculations and comparison to historical observations, Tellus B: Chemical and Physical Meteorology, 2017, Vol. 69, Article 1328945.

Ershov V.V., Lukina N.V., Danilova M.A., Isaeva L.G., Suhareva T.A., Smirnov V.Je., Ocenka sostava dozhdevyh vypadenij v hvojnyh lesah na severnom predele rasprostranenija pri ajerotehnogennom zagrjaznenii (Assessment of the Composition of Rain Precipitation in Coniferous Forests at the Northern Limit of Their Distribution under the Conditions of Aerotechnogenic Pollution), Jekologija, 2020, No 4, pp. 265-274.

Ershov V.V., Lukina N.V., Orlova M.A., Isaeva L.G., Smirnov V.Je., Gorbacheva T.T., Ocenka dinamiki sostava pochvennyh vod severotaezhnyh lesov pri snizhenii ajerotehnogennogo zagrjaznenija vybrosami medno-nikelevogo kombinata (Assessment of Soil-Water Composition Dynamics in the North Taiga Forests upon the Reduction of Industrial Air Pollution by Emissions of a Copper-Nickel Smelter), Sibirskij jekologicheskij zhurnal, 2019. No 1. pp. 119-132.

Ershov V.V., Lukina N.V., Orlova M.A., Zukert N.V., Dynamics of Snowmelt Water Composition in Conifer Forests Exposed to airborne industrial Pollution, Rus. J. of Ecology, 2016, Vol. 47, No 1, pp. 46-52.
Evdokimova G.A., Kislyh E.E., Mozgova N.P., Biologicheskaja aktivnost' pochv v uslovijah ajerotehnogennogo zagrjaznenija na Krajnem Severe (Biological activity of soils under conditions of aerotechnogenic pollution in the Far North), Leningrad, 1984, $121 \mathrm{p}$.

Ferm M., Granat L., Engardt M., Pihl Karlsson G., Danielsson H., Karlsson P.E., Hansen K., Wet deposition of ammonium, nitrate and non-sea-salt sulphate in Sweden 1955 through 2017, Atmospheric Environment: $X$, 2019, Vol. 2, pp. 1-10.

Ferretti M., Beuker E., Calatayud V., Canullo R., Dobbertin M., Eichhorn J., Neumann M., Roskams P., Schaub M., Data quality in field surveys: Methods and results for tree condition, phenology, growth, plant diversity and foliar injury due to ozone. In: Forest Monitoring, Edition: 1, Chapter: 21, UK: Elsevier, pp. 397-414.

Foy C.D., Plant adaptation to acid, aluminiumtoxic soils, Communications in Soil Science and Plant Analysis, 1988, Vol. 19, pp. 959987.

Glazovskaja M.A., Opyt klassifikacii pochv mira po ustojchivosti $\mathrm{k}$ tehnogennym kislotnym vozdejstvijam (Experience in the classification of world soils for resistance to technogenic acid influences), Pochvovedenie, 1990, No 9, pp. 82-96.

Glazovskaja M.A., Principy klassifikacii pochv po opasnosti ih zagrjaznenija tjazhelymi metallami (Principles for the classification of soils by the danger of their pollution by heavy metals), Biol. Nauki, 1989, No 9, pp. 38-47.

Glazovskaja M.A., Problemy i metody ocenki jekologo-geohimicheskoj ustojchivosti pochv $\mathrm{i}$ pochvennogo pokrova $\mathrm{k}$ tehnogennym vozdejstvijam (Problems and methods for assessing the ecological and geochemical resistance of soils and soil cover to technogenic impacts), Pochvovedenie, 1999, No 1, pp. 114-124.

Glazovskij N.F., Zlobina A.I., Uchvatov V.P., Himicheskij sostav snezhnogo pokrova nekotoryh rajonov Verhneokskogo bassejna (The chemical composition of the snow cover in some areas of the Upper Oka basin), Regional'nyj jekologicheskij 
monitoring, Moscow, Nauka, 1983, pp. 6786.

Godbold D.L., Dictus K., Hüttermann A., Influence of aluminum and nitrate on root growth and mineral nutrition of Norway spruce (Picea abies) seedlings, Canadian Journal of Forest Research, 1988, Vol. 18, pp. 1167-1171.

Godbold D.L., Hüttermann A., Aluminium toxicity and forest decline, Proceedings of the National Academy of Sciences of the United States of America, 1988, Vol. 85, pp. 3888-3892.

Godbold D.L., Kettner C., Use of root length elongation studies to determine aluminium and lead toxicity in Picea abies seedlings, Journal of Plant Physiology, 1991, Vol. 138, pp. 231-235.

Graf Pannatier E., Walthert L., Blaser P., Soil solution chemistry in acid forest soils: Are the BC: Al ratios as critical as expected in Switzerland, Journal of Plant Nutrition and Soil Science, Vol. 164, pp. 160-168.

Gundersen P., Nitrogen deposition and the forest nitrogen cycle: Role of denitrification, Forest Ecology and Management, 1991, Vol. 44, pp. 15-28.

Gundersen P., Sevel L., Christiansen J.R. et al., Do indicators of nitrogen retention and leaching differ between coniferous and broadleaved forests in Denmark, Forest Ecology and Management, 2009, Vol. 258, pp. 1137-1146.

Hansen K., Vesterdal L., Bastrup-Birk A., Bille-Hansen J., Are Indicators for Critical Load Exceedance Related to Forest Condition, Water, Air \& Soil Pollution, Vol. 183, pp. 293-308.

Helmisaari H.-S., Mälkönen E., Acidity and nutrient content of throughfall and soil leachate in three Pinus sylvestris stands, Scandinav. J. of Forest Research, 1989, Vol. 4, Issue 1-4, pp.13-28.

Herrmann M., Pust J., Pott R., The chemical composition of throughfall beneath oak, birch and pine canopies in Northwest Germany, Plant Ecology, 2006, Vol. 184, pp. 273-285.

Hrustaleva M.A., Jekogeohimija morennyh landshaftov centra Russkoj ravniny (Ecogeochemistry of moraine landscapes in the center of the Russian Plain), Moscow: Tehnopoligrafcentr, 2002, $315 \mathrm{p}$.

IPCC (2007) Climate Change 2007: The Physical Science Basis. Contribution of Working Group I to the Fourth Assessment Report of the Intergovernmental Panel on Climate Change, Cambridge University Press, Cambridge, United Kingdom and New York, NY, USA.

Jakovljevic T., Marchetto A., Lovreškov L. ye al., Assessment of Atmospheric Deposition and Vitality Indicators in Mediterranean Forest Ecosystems, Sustainability, 2019, Vol. 11, pp. 1-23.

Jarmishko V.T., Jarmishko M.A., Vlijanie pozharov i atmosfernogo zagrjaznenija na strukturu i produktivnost' napochvennogo pokrova i travjano-kustarnichkovogo jarusa sosnovyh lesov na evropejskom severe Rossii (The effect of fires and atmospheric pollution on the structure and productivity of the soil cover and grass-shrub layer of pine forests in the European north of Russia), Rastitel'nye resursy, 2002, Vol. 38, Issue 2, pp. 40-54.

Jarmishko V.T., Ocenka sostojanija podzemnyh organov rastenij $\mathrm{v}$ uslovijah promyshlennogo zagrjaznenija (Assessment of the state of the underground organs of plants under industrial pollution), Vlijanie promyshlennyh predprijatij na okruzhajushhuju sredu: Tez. dokl. na Vsesojuz. Shkole (The impact of industrial enterprises on the environment: Abstracts at the All-Union School), Zvenigorod, Pushhino, 1984, pp. 230-231.

Johnson J., Graf Pannatier E., Carnicelli S. et al., The response of soil solution chemistry in European forests to decreasing acid deposition, Global Change Biology, 2018, Vol. 24, pp. 3603-3619.

Karaban' R.T., Nazarov I.M., Rudneva I.A., Sisigina T.I., O nakoplenii nikelja v pochve i drevesnoj rastitel'nosti lesonasazhdenij, proizrastajushhih vokrug predprijatij cvetnoj metallurgii (On the accumulation of nickel in the soil and woody vegetation of forest stands growing around non-ferrous metallurgy enterprises), Migracija zagrjaznjajushhih veshhestv $v$ pochvah $i$ sopredel'nyh sredah, Leningrad, 1985, pp. 109-117. 
Karpachevskij L.O., Les $i$ lesnye pochvy (Forest and forest soils). Moscow: Lesnaja promyshlennost', 1981, 264 p.

Karpuhin A.I., Jashin I.M., Chernikov V.A., Formirovanie i migracija kompleksov vodorastvorimyh organicheskih veshhestv $\mathrm{s}$ ionami tjazhelyh metallov $\mathrm{v}$ taezhnyh landshaftah Evropejskogo Severa (Formation and migration of complexes of water-soluble organic substances with heavy metal ions in the taiga landscapes of the European North), Izvestija TSHA, 1993, Issue. 2, pp. 107-126.

Kashulina G., Caritat P., Reimann C., Snow and rain chemistry around the "Severonikel" industrial complex, NW Russia: Current status and retrospective analysis, Atmospheric Environment, 2014, Vol. 89, pp. 672-682.

Kislotnye osadki i lesnye pochvy (Acid rain and forest soils), Eds: Nikonov V.V., Kopcik G.N., Apatity: KNTS RAN, 1999, 320 p.

Kljuev N.N., Jakovenko L.M., "Grjaznye" goroda Rossii: faktory, opredeljajushhie zagrjaznenie atmosfernogo vozduha ("Dirty" cities in Russia: factors determining air pollution), Vestnik Rossijskogo universiteta druzhby narodov. Serija jekologija i bezopasnost', 2018, Vol. 26, No 2, pp. 237-250.

Konovalov A.G., Risnik D.V., Levich A.P., Fursova P.V., Obzor podhodov k ocenke jekologicheskogo sostojanija i normirovaniju kachestva pochv (Overview of approaches to environmental assessment and soil quality regulation), Mezhdisciplinarnyj nauchnyj $i$ prikladnoj zhurnal "Biosfera", 2017, Vol. 9, No 3.

Kopanev I.D., Klimaticheskie aspekty izuchenija snezhnogo pokrova (Climatic aspects of the study of snow cover), Leningrad, Gidrometeoizdat, 1982, 239 p.

Kopcik G.N., Lukina N.V., Smirnova I.E., Vlijanie atmosfernogo promyshlennogo zagrjaznenija na sostav pochvennyh rastvorov podzolov (The effect of atmospheric industrial pollution on the composition of soil solutions of podzols), Pochvovedenie, 2007, No 2, pp. 223-234.

Kopcik G.N., Ustojchivost' lesnyh pochv k atmosfernomu zagrjaznenii (Resistance of forest soils to atmospheric pollution),
Moscow: Lesovedenie, 2004, No 4, pp. 6171.

Kopcik S.V., Kopcik G.N., Aljabina I.O., Ocenka riska izbytochnogo postuplenija soedinenij sery $\mathrm{v}$ nazemnye jekosistemy Kol'skogo poluostrova (Assessment of the risk of excess intake of sulfur compounds in terrestrial ecosystems of the Kola Peninsula), Jekologija, 2008, No 5, pp. 347356.

Korhola A., Weckstrom J., Nyman M., Predicting the long-term acidification trends in small subarctic lakes using diatoms, Journal of Applied Ecology, 1999, Vol. 36, pp. 1021-1034.

Kowalska, A., Astel A., Boczoń A., Polkowska $\dot{Z}$., Atmospheric deposition in coniferous and deciduous tree stands in Poland, Atmospheric Environment, 2016, Vol. 133, pp. 145-155.

Kovda V.A., Biogeohimija pochvennogo pokrova (Biogeochemistry of soil cover), Nauka, 1985, 264 p.

Kravchenko I.Ju., Himicheskij sostav pochvennyh vod hvojnyh lesov srednej tajgi Karelii (The chemical composition of soil water in the coniferous forests of the middle taiga of Karelia), $V$ sbornike: Biodiagnostika sostojanija prirodnyh $i$ prirodno-tehnogennyh sistem Materialy HIV Vserossijskoj nauchno-prakticheskoj konferencii c mezhdunarodnym uchastiem (In the collection: Biodiagnostics of the state of natural and natural-technogenic systems Materials of the XIV All-Russian Scientific and Practical Conference with international participation), 2016, pp. 330335.

Kristensen H.L., Gundersen P., Callesen I., Reinds G.J., Throughfall nitrogen deposition has different impacts on soil solution nitrate concentration in European coniferous and deciduous forests, Ecosystems, 2004, Vol. 7, pp. 180-192.

Kudrevatyh I.Ju., Ocenka vzaimosvjazi mezhdu atmosfernym vypadeniem mineral'nogo azota i rastitel'nost'ju v lesnyh jekosistemah (Assessing the relationship between atmospheric deposition of mineral nitrogen and vegetation in forest ecosystems), Jekologija. Izvestija RAN. 
Serija biologicheskaja, 2017, No 2, pp. 181189.

Kurpatov S.V., Mihajluc A.P., Ivanova O.Ju., Formirovanie tehnogennyh nagruzok himicheskogo zagrjaznenija atmosfernogo vozduha v sovremennyh uslovijah razvitija proizvoditel'nyh sil v Krasnojarskom krae (The formation of technogenic loads and chemical pollution of atmospheric air in modern conditions of development of productive forces in Krasnoyarsk region), Rossijskij mediko-biologicheskij vestnik imeni akademika I.P. Pavlova, 2016, Vol. 24, No 4, pp. 17-24.

Lorenz M., Becher G., Forest Condition in Europe, Technical Report of ICP Forests. Work Report of the Thünen Institute for World Forestry 2012/1, ICP Forests, Hamburg, 2012, p. 159.

Lorenz M., Granke O., Deposition measurements and critical loads calculations: monitoring data, results and perspective, Forest - Biogeosciences and Forestry, Vol. 2, pp. 11-14.

Lorenz M., International co-operative programme on assessment and monitoring of air pollution effects on forests - ICP forests, Water Air Soil Pollut, 1995, Vol. 85, pp. 1221-1226.

Lukina N.V., Ershov V.V., Gorbacheva T.T., Orlova M.A., Isaeva L.G., Teben'kova D.N. Assessment of soil water composition in the northern taiga coniferous forests of background territories in the industrially developed region, Eurasian Soil Science, 2018, Vol. 51, No 3, pp. 285-297.

Lukina N.V., Nikonov V.V., Biogeohimicheskie cikly v lesah Severa v uslovijah ajerotehnogennogo zagrjaznenija (Biogeochemical cycles in the forests of the North under aerotechnogenic pollution), Part. 1, Apatity: KNC RAN, 1996, 216 p.

Lukina N.V., Nikonov V.V., Degradational succession of forest ecosystems in the surroundings of $\mathrm{Cu}-\mathrm{Ni}$ smelter in theKola Peninsula, Proceedings of 28th Annual Meeting, Sudbury, Ontario, 2003, [CDROM].

Lukina N.V., Nikonov V.V., Pitatel'nyj rezhim lesov severnoj tajgi (Nutritional regime of northern taiga forests), Apatity: KNC RAN, 1998, 316 p.
Lukina N.V., Poljanskaja L.M., Orlova M.A., Pitatel'nyj rezhim pochv severotaezhnyh lesov (Nutrient regime of soils of northern taiga forests), Moscow: Nauka, 2008, 342 p.

Maas R., Grennfelt P., Towards Cleaner Air. Scientific Assessment Report 2016. EMEP Steering Body and Working Group on Effects of the Convention on Long-Range Transboundary Air Pollution, 2016, p. 50.

Martynjuk A.A., Doronicheva E.V., Rykova T.V., Izmenenie himicheskogo sostava prirodnyh osadkov pod pologom sosnovyh nasazhdenij $\mathrm{V}$ uslovijah tehnogennogo zagrjaznenija sredy (Changes in the chemical composition of natural rainfall under the canopy of pine plantations under conditions of technogenic pollution), Lisovij zhurnal, 2011, No 1, pp. 8-11.

Marunich S.V., Burov A.S., Kuznecova Ju.N., Nedogarko I.V., Transformacija himicheskogo sostava atmosfernyh osadkov pologom drevostoja juzhnotaezhnyh lesov (The transformation of the chemical composition of precipitation by the canopy of the stand of the southern taiga forests), Izvestija RAN. Serija geograficheskaja, 2006, No 4, pp. 52-57.

Matzner E., Meiwes K.J., Long-term development of element fluxes with bulk precipitation and throughfall in two German forests, Journal of Environmental Quality Abstract, 1994, Vol. 23, pp. 162-166.

Medvedev L.V., Shitikova T.E., Alekseenko V.A., Transformacija zhidkih atmosfernyh osadkov drevostojami juzhnoj tajgi (na primere Valdaja) (Transformation of liquid atmospheric precipitation by stands of southern taiga (Valdai as an example), Struktura $i$ funkcionirovanie jekosistem juzhnoj tajgi, Moscow, 1986, pp. 26-55.

Morozova R.M., Kulikova V.K., Rol' atmosfernyh osadkov v krugovorote azota i zol'nyh jelementov v elovyh lesah Karelii (The role of precipitation in the nitrogen and ash cycle in the spruce forests of Karelia), Pochvennye issledovanija $v$ Karelii. Petrozavodsk: In-t lesa KF AN SSSR, 1974, pp. 143-161.

Motuzova G.V., Barsova N.Ju., Karpova E.A., Kocharjan A.G., Sostav lizimetricheskih vod pochv Verhnevolzhskih landshaftov (Composition of lysimetric waters of soils 
of the Upper Volga landscapes), Pochvovedenie, 2009, No 2, pp.1-9.

Motuzova G.V., Pochvenno-himicheskij jekologicheskij monitoring (Soil-chemical environmental monitoring). Moscow: MGU, 2001, 85 p.

Nikonov V.V, Lukina N.V, Bezel' V.S. et al., Rassejannye jelementy $\mathrm{v}$ boreal'nyh leash (Scattered elements in boreal forests), Moscow: Nauka, 2004, 616 p.

Nikonov V.V., Lukina N.V., Vlijanie eli i sosny na kislotnost' i sostav atmosfernyh vypadenij v severo-taezhnyh lesah industrial'no razvitogo regiona (The effect of spruce and pine on the acidity and composition of atmospheric deposition in the north-taiga forests of the industrialized region), Jekologija, 2000, No 2, pp. 97-105.

Nilsson J., Grennfelt P., Critical loads for Sulphur and nitrogen, Miljorapport, 1988, p. 418

Obolkin V.A., Hodzher T.V., Anohin Ju.A. et al., Kislotnost' atmosfernyh vypadenij v regione Bajkala (Acidity of atmospheric deposition in the Baikal region), Meteorologija i gidrologija, 1991, No 1, pp. 55-60.

Pascaud A., Sauvage S., Coddeville P., Nicolas M., Croisé L., Mezdour A., Probst A., Contrasted spatial and long-term trends in precipitation chemistry and deposition fluxes at rural stations in France, Atmospheric Environment, 2016, Vol. 146, pp. 28-43.

P'javchenko N.I., Sibereva Z.A., O roli atmosfernoj pyli v pitanii bolot (On the role of atmospheric dust in the nutrition of swamps), Doklady AN SSSR, 1959, Vol. 124, No 2, pp. 414-417.

Pomeroy J.W., Davies T.D., Jones H.G. et al., Transformations of snow chemistry in the boreal forest: accumulation and volatilization, Hydrol. Process, 1999, Vol. 13, pp. 2257-2273.

Pozdnjakov L.K., O roli osadkov pronikajushhih pod polog lesa, $\mathrm{v}$ processe obmena veshhestv mezhdu lesom i pochvoj (On the role of sediments penetrating under the forest canopy in the process of metabolism between forest and soil), Doklady AN SSSR, 1956, Vol. 107, No 5. pp. 753-756.
Priputina I.V., Bashkin V.N., Jekologicheskie riski v svjazi s tehnogennym zagrjazneniem okruzhajushhej sredy: analiz podhodov i metodov ocenki (Environmental risks associated with anthropogenic pollution of the environment: analysis of approaches and assessment methods), Problemy analiza riska, 2012, Vol. 9, No 5, pp. 4-25.

Pristova T.A., Vlijanie drevesnogo pologa listvenno-hvojnogo nasazhdenija na himicheskij sostav osadkov (The influence of deciduous-coniferous tree canopy on the chemical composition of sediments), Lesovedenie, 2005, No 5, pp. 49-55.

Pristova, T.A, Vasilevich M.I., Himicheskij sostav snezhnogo pokrova $\mathrm{V}$ lesnyh jekosistemah $\mathrm{v}$ zone ajerotehnogennogo vlijanija celljulozno-bumazhnogo proizvodstva (CBP) (The chemical composition of the snow cover in forest ecosystems in the area of aerotechnogenic influence of pulp and paper production (PPI), Izvestija Samarskogo nauchnogo centra Rossijskoj akademii nauk, 2010, Vol. 12, No 1(9), pp. 2313-2316.

Ratkin N.E., Asming V.Je., Koshkin V.V., Vlijanie prirodnyh lokal'nyh faktorov na zagrjaznenie snezhnogo pokrova (na primere Pechengskogo rajona) (The influence of natural local factors on snow cover pollution (by the example of the Pechenga district)), Vestnik MGTU, 1988, Vol. 1, No 3, pp. 151-160.

Ratkin N.E., Kolichestvennaja ocenka ajerotehnogennogo potoka veshhestva na podstilajushhuju poverhnost' raschetnym metodom (Quantitative assessment of aerotechnogenic substance flow to the underlying surface by calculation method), Vestnik MGTU, 2000, Vol. 3, No 1, pp. 145164.

Raudina T.V., Pochvennyj rastvor: ot klassicheskih predstavlenij k sovremennym ponjatijam (Soil solution: from classical concepts to modern concepts), Reflection Bio-Geo-antropospheral interactions in soils and soil cover, Collection of materials $\mathrm{V}$ International Scientific Conference, dedicated to the 85th anniversary of the opening of the first university department of Soil Science in Siberia September 7-11, 2015, Tomsk, Russia, 2015, pp. 87-93. 
Reinds G.J., Groenenberg J.E., Vrieset W., Critical Loads of copper, nickel, zinc, arsenic, chromium and selenium for terrestrial ecosystems at a European scale, Wageningen, Alterra, 2006, p. 46.

Robakidze E.A., Torlopova N.V., Bobkova K.S., Himicheskij sostav zhidkih atmosfernyh osadkov $\mathrm{v}$ starovozrastnyh el'nikah srednej tajgi (The chemical composition of liquid atmospheric precipitation in old-growth spruce forests of the middle taiga), Geohimija, 2013, No 1, pp. 72-83.

Rode A.A., Pochvovedenie (Soil science). Moscow: Goslesbumizdat, 1955, 524 p.

Sawicka K., Monteith D.T., Vanguelova E.I., Wade A.J. Clark J.M., Fine-scale temporal characterization of trends in soil water dissolved organic carbon and potential drivers, Ecological Indicators, 2016, Vol. 68, pp. 36-51.

Schöpp W., Posch M., Mylona S., Johansson $M$ Long-term development of acid deposition (1880-2030) in sensitive freshwater regions in Europe, Hydrol Earth Syst Sci, 2003, pp. 436-446.

Shepel' K.S., Geoekologicheskaya otsenka zagryazneniya pochv $\mathrm{V}$ rayone raspolozheniya predpriyatiya gornometallurgicheskogo kompleksa Urala (Geoecological assessment of soil pollution in the area of the mining and metallurgical complex of the Ural), Problemy nedropol'zovaniya, 2019, No 2, pp. 171176.

Shil'cova G.V., Rol' sosnovyh biogeocenozov zapovednika «Kivach» V formirovanii kislotnosti i sostava prirodnyh vod (The role of pine biogeocenoses of the Kivach reserve in the formation of acidity and composition of natural waters), Trudy Karel'skogo nauchnogo centra RAN, issue 10, Petrozavodsk, 2006, pp. 173-179.

Smit U.H., Les $i$ atmosfera (Forest and atmosphere), Moscow: Progress, 1985, 430 p.

Sultanbaeva R.R., Kopcik G.N., Smirnova I.E., Kopcik S.V., Postuplenie i migracija rastvorimogo organicheskogo ugleroda $\mathrm{V}$ pochvah lesnyh jekosistem podzony shirokolistvenno-hvojnyh lesov (The intake and migration of soluble organic carbon in the soils of forest ecosystems of the subzone of deciduous-coniferous forests), Vestnik Moskovskogo universiteta. Ser. 17: Pochvovedenie, 2015, No 4, pp. 37-42.

Svedrup H., Warfvinge P., Effect of soil acidification on the growth of trees and plants as expressed by the $(\mathrm{Ca}+\mathrm{Mg}+\mathrm{K}) / \mathrm{Al}$ ratio, Reports in Environmental Engineering and Ecology, 1993, Vol. 2, pp. 123.

Tentjukov M.P., Osobennosti formirovanija zagrjaznenija snezhnogo pokrova: moroznoe kondensirovanie tehnogennyh jemissij (na primere rajonov neftedobychi $\mathrm{v}$ bol'shezemel'skoj tundre) (Features of the formation of snow cover pollution: frosty condensation of technogenic emissions (on the example of oil production areas in the Bolshezemelskaya tundra), Kriosfera zemli, 2007, Vol. 11, No 4, pp. 31-41.

Thimonier A., Measurement of atmospheric deposition under forest canopies: Some recommendations for equipment and sampling design, Environmental Monitoring and Assessment, 1998, Vol. 52, pp. 353-387.

Thimonier A., Schmitt M., Waldner P., Rihm B., Atmospheric deposition on Swiss Longterm forest ecosystem research (LWF) plots, Environmental Monitoring and Assessment, 2005, Vol. 104, pp. 81-118.

Tjazhelye metally $v$ okruzhajushhej srede (Heavy metals in the environment), Moscow: Izd-vo MGU, 1980, 80 p.

Trubicina O.P., Analiz geojekologicheskogo sostojanija atmosfernogo vozduha $i$ osadkov severa Russkoj ravniny po dannym monitoring (Analysis of the geoecological state of atmospheric air and precipitation in the north of the Russian Plain according to monitoring data), Vestnik Pomorskogo universiteta. Ser: Estestvennye nauki, 2008, No 3, pp. 35-42.

Uchvatov V.P., Glazovskij N.F., Transformacija himicheskogo sostava prirodnyh vod $\mathrm{v}$ lesnom landshafte kak pokazatel' ego biogeohimicheskogo funkcionirovanija (The transformation of the chemical composition of natural waters in a forest landscape as an indicator of its biogeochemical functioning), Izvestija $A N$ SSSR. Ser. Geogr, 1984, No 1, pp. 101-109. 
Waldner P., Schaub M., Graf Pannatier E., Schmitt M., Thimonier A., Walthert L., Atmospheric Deposition and Ozone Levels in Swiss Forests: Are Critical Values Exceeded, Environmental Monitoring and Assessment, 2007, Vol. 128, pp. 5-17.

Waldner P., Thimonier A., Graf Pannatier E. et al., Exceedance of critical loads and of critical limits impacts tree, Annals of Forest Science, 2015, Vol. 72, pp. 929-939.

van Dobben, H., De Vries W., Relation between forest vegetation, atmospheric deposition and site conditions at regional and European scales, Environmental Pollution, Vol. 158, pp. 921-933.

Vanguelova E.I., Benham S., Pitman R. et al., Durrant Houston T. Chemical fluxes in time through forest ecosystems in the UK - Soil response to pollution recovery, Environmental Pollution, Vol. 158, pp. 1857-1869.

Vasilenko V.N., Nazarov I.M., Fridman Sh.D., Issledovanie dal'nego perenosa sul'fatov $\mathrm{v}$ Sovetskoj Arktike po zagrjazneniju snezhnogo pokrova (Study of the longrange transport of sulfates in the Soviet Arctic on snow pollution), Meteorologija $i$ gidrologija, 1985, No 4, pp. 114-117.

Vernadskij V.I., Izbrannye sochinenija (Selected Works), Moscow: Izd-vo AN SSSR, 1960, 420 p.

Verstraeten A., Neirynck J., Genouw G., Cools N., Roskmans P., Hens M., Impact of declining atmospheric deposition on forest soil solution chemistry in Flanders, Belgium, Atmospheric Environment, 2012, Vol. 62, pp. 50-63.

Voejkov A.I., Vlijanie snegovoj poverhnosti na klimat (The effect of snow on climate), Leningrad; Moscow, Izd-vo AN SSSR, 1949, Vol. 2, 531 p.

Voevodova Z.I., Vozmozhnost' opredelenija vlijanija zagrjaznenija atmosfery na vodnye resursy putem otbora prob snega. in: Vlijanie hozjajstvennoj dejatel'nosti cheloveka na vodnye resursy Komi ASSR (The impact of human activities on the water resources of the Komi ASSR), Syktyvkar, 1979, pp. 80-88.

Vorobejchik E.L., Kajgorodova S.Ju., Mnogoletnjaja dinamika soderzhanija tjazhelyh metallov $\mathrm{v}$ verhnih gorizontah pochv $\mathrm{v}$ rajone vozdejstvija medeplavil'nogo zavoda $\mathrm{v}$ period sokrashhenija ob'emov ego vybrosov (Long-term dynamics of the content of heavy metals in the upper horizons of soils in the area affected by the smelter during the period of reduction of its emissions), Pochvovedenie, 2017, No 8, pp. 10091024.

Zajceva A.O., Tehnogennye istochniki himicheskogo zagrjaznenija atmosfery Krasnojarskogo kraja (Technogenic sources of cemical pollution sources of the atmosphere Krasnoyarsk region), Aktual'nye problemy aviacii i kosmonavtiki, 2016. Vol.1, No 12, pp. 956-958. 


\title{
MONITORING THE COMPOSITION OF ATMOSPHERIC AND SOIL WATERS IN FOREST ECOSYSTEMS: ACHIEVEMENTS AND PERSPECTIVES
}

\author{
V.V. ERSHOV \\ Institute of Industrial Ecology Problems of the North,Kola Scientific Center, Russian Academy of \\ Sciences, Akademgorodok 14a, Murmansk district, Apatity, 184209 Russia \\ E-mail: Slavo91@gmail.com \\ Received 20.04.2020 \\ Accepted 28.05.2020
}

The article gives an overview of Russian and foreign studies devoted to the composition of atmospheric deposition and soil waters in forest ecosystems. It is concluded that insufficient attention is paid to the transformation of the chemical composition of precipitation by forest ecosystems, taking into account the influence of the species composition of the stand and the mosaic structure of the biogeocenosis (under-crown, inter-crown spaces, open areas). In European studies, the composition of atmospheric deposition and lysimetric waters is usually studied over many years allowing detection of long-term trends in changes in the composition of atmospheric and soil waters and identification of the factors of these changes. Such long-term (over 10 years) constant observations on the influence of technogenic pollution on the composition and properties of atmospheric and soil waters were not carried out in any Russian publications. This task is very relevant for Russia and especially for industrially developed regions.

Key words: forest biogeocenoses, air pollution, atmospheric deposition, soil water, monitoring, long-term dynamics, critical loads.

Рецензент: к.б.н., н.с. Солодовников А.Н. 